\title{
Mercury in the Walker River Basin, Nevada and California-Sources, Distribution, and Potential Effects on the Ecosystem
}

Scientific Investigations Report 2004-5147

Prepared in cooperation with the U.S. FISH AND WILDLIFE SERVICE

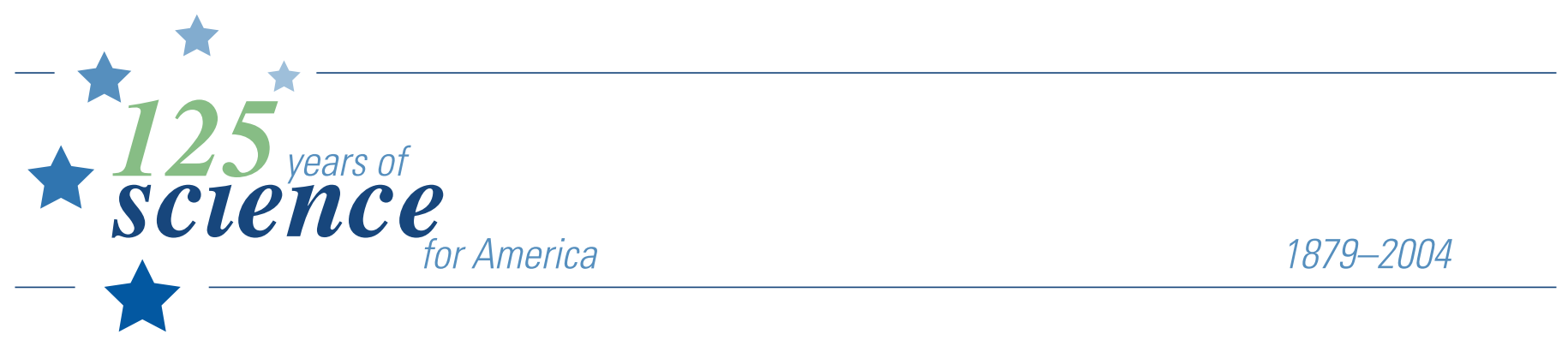

U.S. Department of the Interior

U.S. Geological Survey 
(Back of Cover) 
U.S. Department of the Interior

U.S. Geological Survey

\section{Mercury in the Walker River Basin, Nevada and California-Sources, Distribution, and Potential Effects on the Ecosystem}

By Ralph L. Seiler, Michael S. Lico, Stanley N. Wiemeyer, and David C. Evers

Scientific Investigations Report 2004-5147

Prepared in cooperation with the

U.S. FISH AND WILDLIFE SERVICE

Carson City, Nevada 


\title{
U.S. DEPARTMENT OF THE INTERIOR GALE A. NORTON, Secretary
}

\author{
U.S. GEOLOGICAL SURVEY
}

CHARLES G. GROAT, Director

Any use of trade, product, or firm names in this publication is for descriptive purposes only and does not imply endorsement by the U.S. Government

For additional information contact:

District Chief

U.S. Geological Survey

333 West Nye Lane, Room 203

Carson City, NV 89706-0866

email: GS-W-NVpublic-info@usgs.gov

http://nevada.usgs.gov
Copies of this report can be purchased from:

U.S. Geological Survey Information Services

Building 810

Box 25286, Federal Center

Denver, CO 80225-0286 
CONTENTS

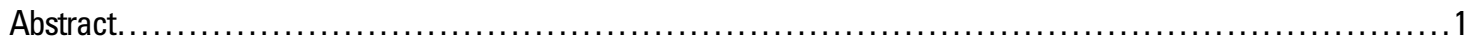

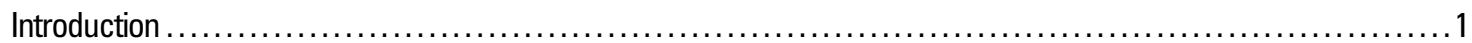

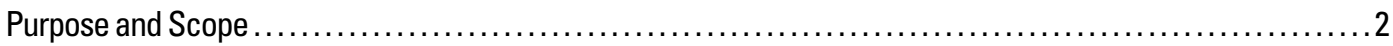

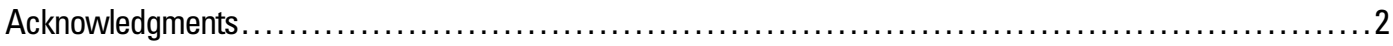

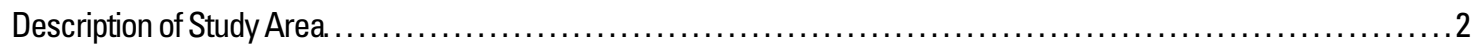

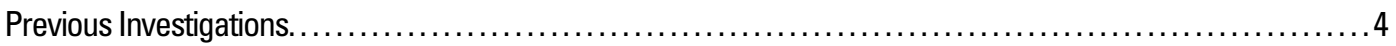

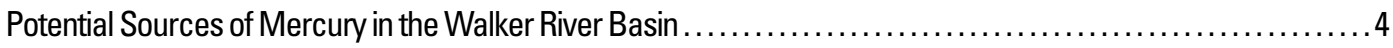

Weathering of Naturally Occurring Mercury Minerals and Geothermal Activity .................... 4

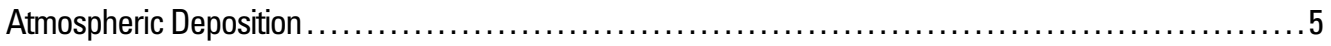

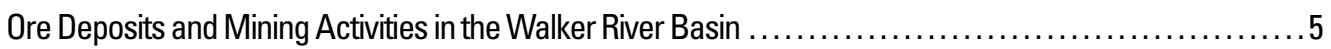

Military Activities . . . . . . . .

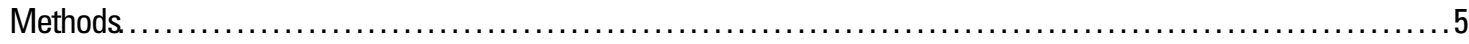

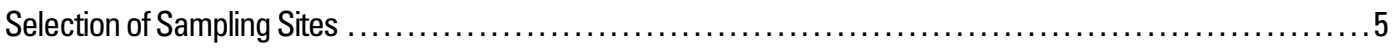

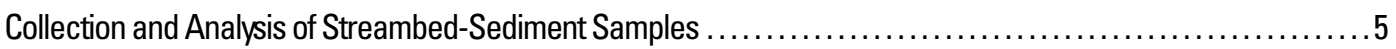

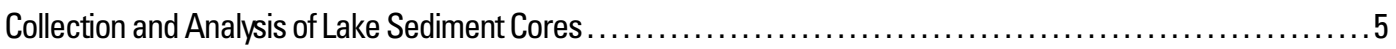

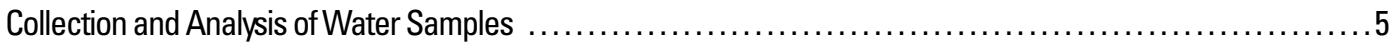

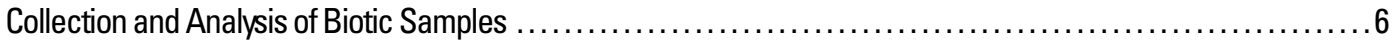

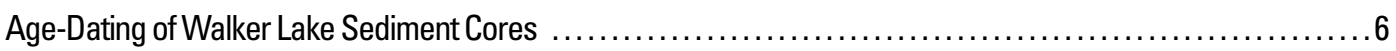

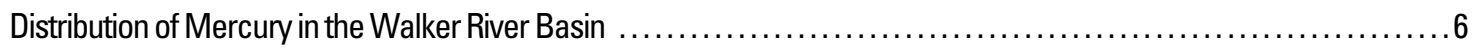

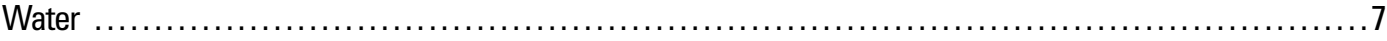

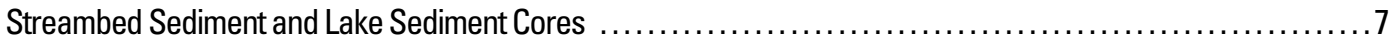

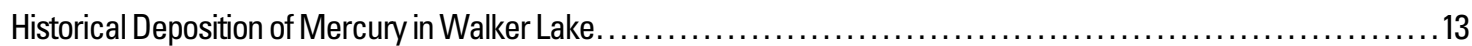

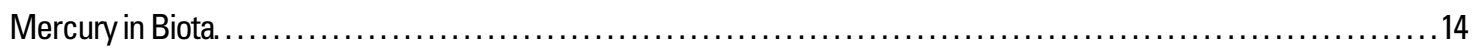

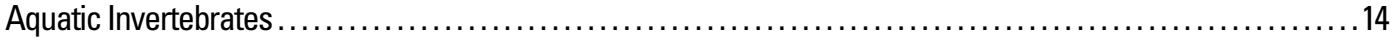

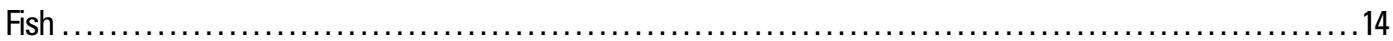

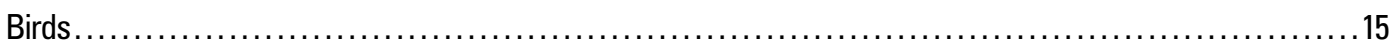

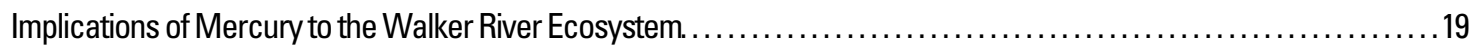

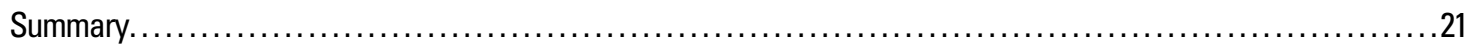

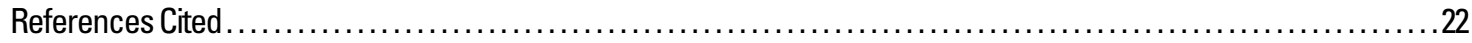

PLATE

Map showing hydrologic features and locations of stream-gaging stations, sampling sites, geothermal springs, and ore deposits in the Walker River Basin, Nevada and California 


\section{FIGURES}

1. Map showing hydrologic features, locations of stream-gaging stations and sampling sites in the Walker River

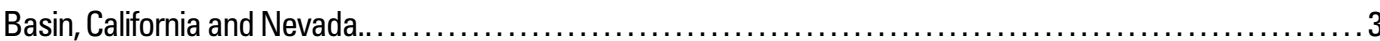

2. Graph showing total-mercury concentrations in sediment as a function of depth in Walker Lake, Nevada ....... 12

3. Graph showing relation between total-mercury and methylmercury concentrations in streambed-sediment

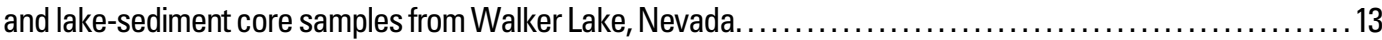

4. Graph showing relation between fish length and mercury concentration in tui chub from Walker Lake,

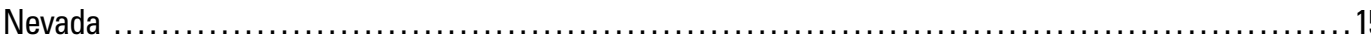

5. Graph showing relation between body weight and total-mercury concentration in blood from common loons at Walker Lake, Nevada

6. Graph showing relation between total-mercury concentration in 20-25 centimeter yellow perch and blood from common loons collected in western Maine...

\section{TABLES}

1. Concentrations of total mercury and methylmercury in water and sediment samples at surfacewater sites in the Walker River Basin, 2000-2001. 8

2. Concentrations of total mercury and methylmercury in water and sediment samples at lake

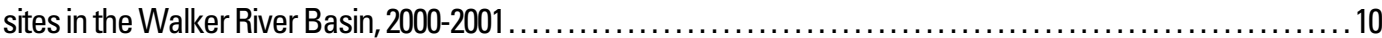

3. Activities of lead-210 and cesium-137 in sediment cores from site WL4, Walker Lake, Nevada ............... 13

4. Concentrations of total mercury in invertebrate and fish samples from the Walker River Basin, Nevada 1999-2001. 16

5. Concentrations of total mercury in common loons from Walker Lake, Nevada, 1998-2001 . ................... 18

\section{CONVERSION FACTORS AND ABBREVIATED WATER-QUALITY UNITS}

\begin{tabular}{rcl}
\hline Multiply & By & To obtain \\
\hline acre-foot (acre-ft) & 1,233 & cubic meter $\left(\mathrm{m}^{3}\right)$ \\
foot (ft) & 0.3048 & meter $(\mathrm{m})$ \\
gallon (gal) & 3.785 & liter $(\mathrm{L})$ \\
inch (in.) & 2.54 & centimeter $(\mathrm{cm})$ \\
inch (in.) & 25.4 & millimeter $(\mathrm{mm})$ \\
mile (mi) & 1.609 & kilometer $(\mathrm{km})$ \\
ounce, fluid (oz) & 0.0296 & liter $(\mathrm{L})$ \\
ounce, avoirdupois (oz) & 28.35 & gram $(\mathrm{g})$ \\
pound (lb) & 0.4536 & kilogram $(\mathrm{kg})$ \\
square foot (ft $\left.{ }^{2}\right)$ & 0.0929 & square meter $\left(\mathrm{m}^{2}\right)$ \\
ton (short) & 0.9072 & megagram $(\mathrm{Mg})$ \\
\hline
\end{tabular}

\section{ABBREVIATED WATER-QUALITY AND OTHER UNITS}

$\mu \mathrm{g} / \mathrm{L}$, microgram per liter $\mu \mathrm{g} / \mathrm{g}$, microgram per gram $\mu \mathrm{g} / \mathrm{m}^{2}$, microgram per meter square $\mathrm{ng} / \mathrm{g}$, nanogram per gram ng/L, nanogram per liter
$\mathrm{pCi} / \mathrm{g}$, picocuries per gram $\mathrm{mm}$, millimeter $\mathrm{mL}$, milliliter $\mathrm{kg}$, kilogram 


\title{
Mercury in the Walker River Basin, Nevada and California-Sources, Distribution, and Potential Effects on the Ecosystem
}

\author{
By Ralph L. Seiler ${ }^{1}$, Michael S. Lico ${ }^{1}$, Stanley N. Wiemeyer ${ }^{2}$, and David C. Evers ${ }^{3}$
}

\section{Abstract}

Mercury is one of the most serious contaminants of water, sediment, and biota in Nevada because of its use during $19^{\text {th }}$ century mining activities to recover gold and silver from ores. In 1998, mercury problems were discovered in the Walker River basin of California and Nevada when blood drawn from three common loons from Walker Lake was analyzed and found to have severely elevated mercury levels. From 1999 to 2001, the U.S. Geological Survey and the U.S. Fish and Wildlife Service collected water, sediment, and biological samples to determine mercury sources, distribution, and potential effects on the Walker River Basin ecosystem.

Total-mercury concentrations ranged from 0.62 to 57.11 $\mathrm{ng} / \mathrm{L}$ in streams from the Walker River system and ranged from 1.02 to $26.8 \mathrm{ng} / \mathrm{L}$ in lakes and reservoirs. Total-mercury concentrations in streambed sediment ranged from 1 to 13,600 $\mathrm{ng} / \mathrm{g}$, and methylmercury concentrations ranged from 0.07 to $32.1 \mathrm{ng} / \mathrm{g}$. The sediment-effects threshold for mercury for freshwater invertebrates is $200 \mathrm{ng} / \mathrm{g}$, which was exceeded at nine stream sites in the Walker River Basin. The highest mercury concentrations were in streams with historic mines and milling operations in the watershed. The highest mercury concentration in sediment, 13,600 ng/g, was found in Bodie Creek near Bodie, Calif., a site of extensive gold mining and milling activities during the $19^{\text {th }}$ century.

Sediment cores taken from Walker Lake show total-mercury concentrations exceeding $1,000 \mathrm{ng} / \mathrm{g}$ at depths greater than $15 \mathrm{~cm}$ below lake bottom. The presence of ${ }^{137} \mathrm{Cs}$ above $8 \mathrm{~cm}$ in one core indicates that the upper $8 \mathrm{~cm}$ was deposited sometime after 1963 . The mercury peak at $46 \mathrm{~cm}$ in that core, $2,660 \mathrm{ng} / \mathrm{g}$, likely represents the peak of mining and gold extraction in the Bodie and Aurora mining districts between 1870 and 1880.

Mercury concentrations in aquatic invertebrates at all sites downstream from mining activities in the Rough Creek watershed, which drains the Bodie and Aurora mining districts, were elevated (range 0.263 to $0.863 \mu \mathrm{g} / \mathrm{g}$, dry weight). Mercury concentrations in the Walker Lake tui chub, the most abundant and likely prey for common loons, ranged from approximately

\footnotetext{
${ }^{1}$ U.S. Geological Survey, Carson City, Nev.

${ }^{2}$ U.S. Fish and Wildlife Service, Reno, Nev.

${ }^{3}$ BioDiversity Research Institute, Gorham, Maine
}

$0.09 \mu \mathrm{g} / \mathrm{g}$ to approximately $0.9 \mu \mathrm{g} / \mathrm{g}$ (wet weight). Larger tui chub in the lake, which are most likely older, had the highest mercury concentrations.

Blood samples from 94 common loons collected at Walker Lake between 1998 and 2001 contained a mean mercury concentration of $2.96 \mu \mathrm{g} / \mathrm{g}$ (standard deviation $1.72 \mu \mathrm{g} / \mathrm{g}$ ). These levels were substantially higher than those found in more than 1,600 common loons tested across North America. Among the 1,600 common loons, the greatest blood mercury concentration, $9.46 \mu \mathrm{g} / \mathrm{g}$, was from a loon at Walker Lake. According to risk assessments for northeastern North America, blood mercury concentrations exceeding $3.0 \mu \mathrm{g} / \mathrm{g}$ cause behavioral, reproductive, and physiological effects. At least 52 percent of the loons at Walker Lake are at risk for adverse effects from mercury on the basis of their blood-mercury concentrations. The larger loons staging in the spring are the most at risk group.

The elevated mercury levels found in tui chub and common loons indicate that there is a potential threat to the well being and reproduction of fish and wildlife that use Walker Lake. Wildlife that use Weber Reservoir may also be at risk because it is the first reservoir downstream from mining activities in the Bodie and Aurora areas and mercury concentrations in sediment were elevated. Additional data on mercury concentrations in top level predators, such as piscivorous fish and birds, are needed to assess public health and other environmental risks.

\section{Introduction}

Mercury is one of the most serious contaminants of water, sediment, and biota in Nevada because of its use during $19^{\text {th }}$ century mining activities to recover gold and silver from ores. Approximately 200,000 flasks of mercury, each weighing 76 pounds, were imported from California for use in the Comstock Mining area near Virginia City (Bailey and Phoenix, 1944, p. 5), and most of this escaped to the Carson River (Smith, 1943, p. 257). In August 1990, the U.S. Environmental Protection Agency listed the Carson River from Carson City to its terminus in the Carson Desert as a Superfund site for remediation of mercury contamination (Horton, 1997). In 1993, the Nevada State Division of Health promulgated a fish consumption advisory for all fish caught in the Carson River between Dayton and the Lahontan Reservoir dam. 


\section{Mercury in the Walker River Basin, Nevada and California-Sources, Distribution and Potential Effects on the Ecosystem}

In 1998, mercury problems were discovered in the Walker River Basin of California and Nevada (fig. 1). Walker Lake, at the terminus of the Walker River, is a stop-over resting and feeding location for migrating common loons (Gavia immer), western grebes (Aechmophorus occidentalis), Clark's grebes (Aechmophorus clarkii), and other water birds that are dependent on the few large waterbodies with ample fish in the intermountain west. In 1998, six common loons were captured at Walker Lake by the BioDiversity Research Institute (BRI) and samples of their blood and feathers were analyzed for mercury as part of a large North American study of mercury (Evers and others, 1998). Results from these samples revealed that three of these birds had elevated blood mercury levels when compared to other studies across North America (Evers and others, 1998; Meyer and others, 1998; Scheuhammer and others, 1998).

As a result of this discovery, the U.S. Fish and Wildlife Service (USFWS) began collecting invertebrate and fish samples in the basin for mercury analysis. The U.S. Geological Survey (USGS), in cooperation with USFWS, collected sediment and water samples from streams and lakes in the Walker River basin in the fall of 2000 to determine potential sources of mercury. In the fall of 2001, additional sediment samples were collected using data collected in 2000 as a guide for areas where additional data were needed. The emphasis was on collecting sediment samples because mercury has a tendency to be in sediments rather than water, because many of the tributary streams were dry in the fall during sample collection.

\section{Purpose and Scope}

The purpose of this report is to describe the distribution of mercury and methylmercury in bottom sediment of streams and lakes, water, and biota in the Walker River Basin and to evaluate the potential effects of mercury on the ecosystem. Potential sources of mercury within the basin are addressed in this report. The scope of this report emphasizes data collected from 1998 to 2001 from streams and lakes throughout the Walker River basin by the USGS, USFWS, and BRI, but uses previously published data from other investigators in the Walker River Basin.

\section{Acknowledgments}

The authors wish to acknowledge the Walker River Indian Tribe for access to sampling sites at Weber Reservoir and the Walker River on the Walker River Indian Reservation. The contribution of Daniel R. Engstrom, Director of the St. Croix Watershed Research Station, Minnesota, who provided analysis of isotopes used to age-date the sediment cores from Walker Lake is appreciated. The assistance of Christopher N. Drake of the Nevada Department of Wildlife, who led fish sampling efforts at Walker Lake in May 2000, is appreciated. We also acknowledge Mike Yates and Mark Fuller of the Center for Conservation Research and Technology as the leaders of the loon-related research effort. Field assistance by Larry Neel,
Nevada Department of Wildlife; Jim Paruk, Northland College, Chris DeSorbo and Lucas Savoy, BioDiversity Research Institute is appreciated.

\section{Description of Study Area}

The Walker River Basin (fig. 1) is located in west-central Nevada and eastern California and covers an area of approximately 4,000 $\mathrm{mi}^{2}$. The principal hydrologic features of the Basin are the East and West Forks of the Walker River and the main stem of the river. The river system begins at the crest of the Sierra Nevada and flows northward to Mason Valley, where the river turns south and ultimately discharges into Walker Lake. Walker Lake is one of a few large perennial terminal lakes in the western United States.

Flow in the Walker River is mainly from precipitation in the eastern Sierra Nevada of California. Total streamflow in the West and East Forks of the Walker River averaged 327,000 acre-ft/yr for the period 1939-93 (Thomas, 1995). Water is consumed by evaporation from ground and surface water and transpiration by crops, pastures, and native vegetation.

The principal use of water in the Walker River Basin is for irrigation. Several reservoirs have been constructed to control releases of water downstream and include Upper and Lower Twin Lakes, Bridgeport Reservoir, Topaz Lake, and Weber Reservoir. A chronological history of the Walker River and water related issues was provided by Horton (1996). Topaz Reservoir was finished in 1922 and at that time, began storing water from the West Fork of the Walker River for irrigation purposes. One year later (1923), Bridgeport Reservoir was completed on the East Fork of the river. Finally, in 1934, Weber Reservoir was built on the mainstem and held water for irrigation on the Walker River Indian Reservation.

Since the early 1900's, diversion of water from the Walker River for agricultural purposes in Bridgeport, Antelope, Smith, and Mason Valleys has greatly decreased the flow of water into Walker Lake. Changes in flow to Walker Lake, resulting from anthropogenic and natural causes, resulted in an approximately $140 \mathrm{ft}$ drop in lake stage between 1882 and 1994 (Thomas, 1995). Many changes to the physical, chemical, and ecological features of the lake have occurred because of the decline of the lake level. Dissolved solids concentrations have increased from about 2,500 mg/L in 1882 to 13,300 mg/L in 1994 (Thodal and Tuttle, 1996) and 14,000 mg/L in 2002 (Nevada Division of Environmental Protection, <http://ndep.nv.gov/bwqp/ wl.xls $>$ ).

Numerous ore deposits within the Walker River Basin (plate 1) have been mined since the late 1800's. The Aurora and Bodie mining districts operated at peak levels from about 1860 to 1880 with each extracting about $\$ 30$ million in gold from mills operating in the Rough Creek drainage (Paher, 1980; plate 1) which is tributary to the East Fork of the Walker River. At one point in 1864, there were 17 active amalgamation mills in Aurora (Ross, 1961); the largest was the 30-stamp Del Monte mill on Bodie Creek. 


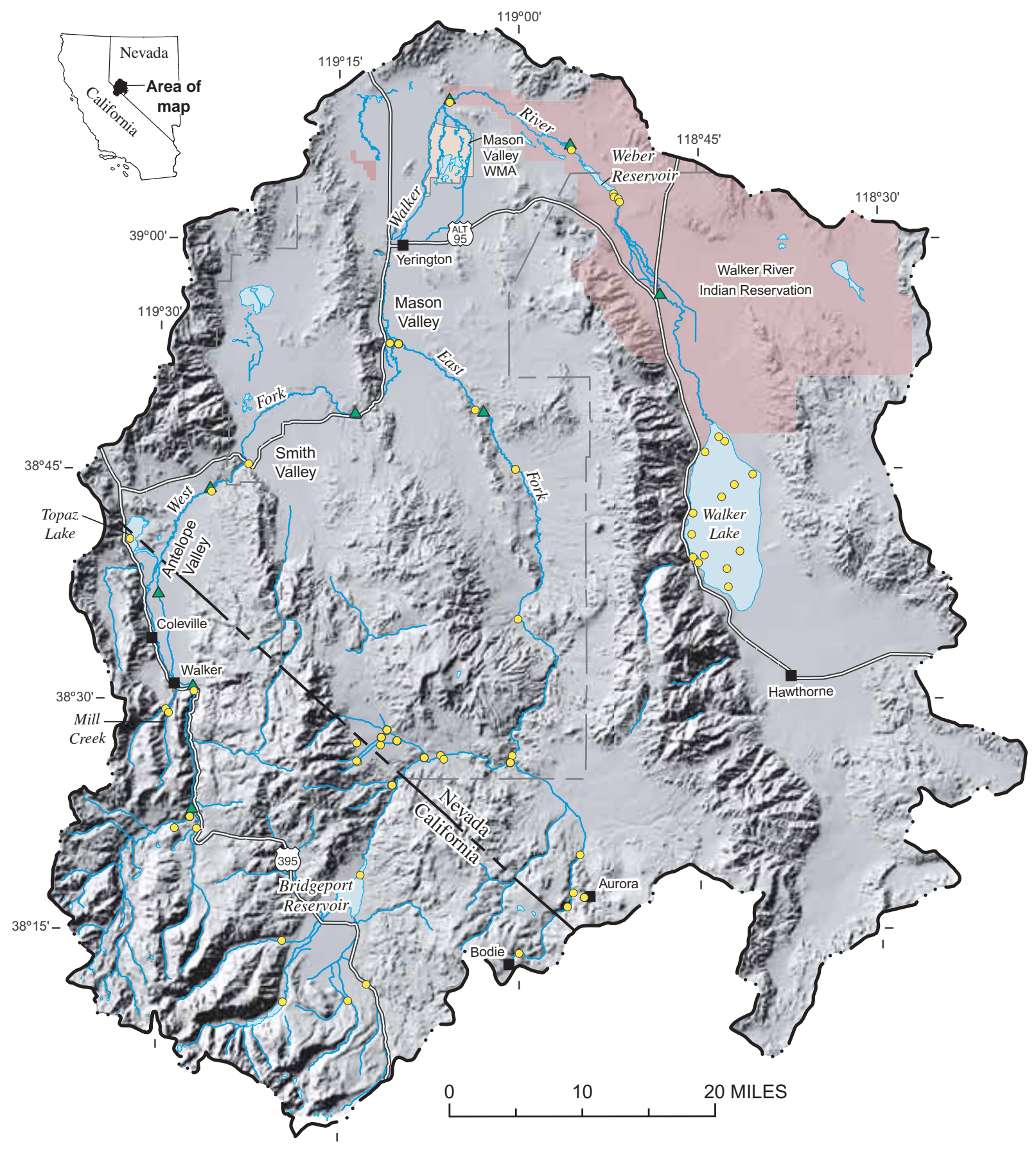

Base from U.S. Geological Survey digital data 1:100,000 1979-1985 Universal Transverse Mercator projection, Zone 11

Shaded Relief Base from National Elevation Dataset;

Sun illumination from northwest at 45 degrees above horizon

\section{EXPLANATION}

- - - Walker River Basin boundary

$\Delta \quad$ Stream gaging station

- Sampling site

Figure 1. Map showing hydrologic features, locations of stream-gaging stations and sampling sites in the Walker River Basin, California and Nevada (see plate 1 for corresponding number for sampling sites listed in tables 1,2, and 4). 


\section{Mercury in the Walker River Basin, Nevada and California-Sources, Distribution and Potential Effects on the Ecosystem}

Many wildlife species depend on wetlands and lakes in the basin, and nearly 250 wildlife species have been identified in the lower Walker River Basin (Thodal and Tuttle, 1996). In the past, Walker Lake supported a population of Lahontan cutthroat trout (Oncorhynchus clarki henshawi), however, since 1948 the species has been maintained in Walker Lake exclusively through hatchery propagation (Thodal and Tuttle, 1996). Lahontan cutthroat trout, a threatened species, inhabits the lower basin downstream from Weber Dam, but since 1948 the population has been maintained exclusively by release of hatchery-propagated fish into Walker Lake (Thodal and Tuttle, 1996). Several isolated populations of the species also occur in headwater streams. Walker Lake is an important resting and staging area for birds using the Pacific Flyway. As many as 1,400 common loons stage during migration at Walker Lake during spring and fall to feed and rest (Yates, M.A., Center for Conservation Research and Technology, written commun., 2002).

\section{Previous Investigations}

Benson and Spencer (1983) analyzed surface-water and bed-sediment samples for mercury concentrations in the Walker River Basin. In Walker Lake, the total-mercury concentrations in bottom-sediment samples collected just below the watersediment interface ranged from $60 \mathrm{ng} / \mathrm{g}$ to $2,000 \mathrm{ng} / \mathrm{g}$. The greatest concentrations were along the eastern shore, in the middle of the lake and in the delta near the mouth of the river. A core taken from the south-central part of the lake shows concentrations of about $1,000 \mathrm{ng} / \mathrm{g}$ near the sediment surface with the greatest concentration, $81,000 \pm 46,000 \mathrm{ng} / \mathrm{g}$, at a depth of $90 \mathrm{~cm}$. This large value is similar in magnitude to the values for lake cores from Lahontan Reservoir reported by Hoffman and Taylor (1998; 4,000 to $15,000 \mathrm{ng} / \mathrm{g}$ ) and also to values for bottom sediment $(13,100 \mathrm{ng} / \mathrm{g})$ at Stillwater Slough in the Carson Desert (Hoffman and Thomas, 2000). The smallest mercury concentration of $300 \mathrm{ng} / \mathrm{g}$, was $100 \mathrm{~cm}$ at the bottom of the core, and immediately below the greatest concentration.

Thodal and Tuttle (1996) investigated the effects of irrigation drainage on water quality and biota in the Walker River Basin, with an emphasis on the Walker River Indian Reservation (fig. 1). Mercury was not detected in water samples from 26 sites in the basin; however, the laboratory reporting level (lrl) was $100 \mathrm{ng} / \mathrm{L}$, which was much higher than the level used in this study $(0.04 \mathrm{ng} / \mathrm{L})$. Mercury was $20 \mathrm{ng} / \mathrm{g}$ in bottom-sediment samples from seven sites in the basin. Mercury concentrations (dry weight) in biota ranged from $<0.1$ to $0.55 \mu \mathrm{g} / \mathrm{g}$ in aquatic plants; $<0.19$ to $2.78 \mu \mathrm{g} / \mathrm{g}$ in aquatic invertebrates; 0.32 to $1.31 \mu \mathrm{g} / \mathrm{g}$ in fish; 0.33 to $5.28 \mu \mathrm{g} / \mathrm{g}$ in bird eggs; 1.89 to $2.06 \mu \mathrm{g} / \mathrm{g}$ in bird livers; and 0.36 to $0.99 \mu \mathrm{g} / \mathrm{g}$ in bird muscle.

\section{Potential Sources of Mercury in the Walker River Basin}

Mercury contamination is often viewed as a global problem because mercury vapor $\left(\mathrm{Hg}^{0}\right)$ has a long atmospheric residence time and because mercury contamination of aquatic environments has been found at locations distant from industrial sources (Engstrom and Swain, 1997). Potential sources of mercury in the Walker River Basin include the weathering of naturally occurring minerals, geothermal springs, deposition of atmospheric mercury from regional and global sources, and industrial and mining activities in the basin.

\section{Weathering of Naturally Occurring Mercury Minerals and Geothermal Activity}

Cinnabar, $\mathrm{HgS}$, is the most important mercury bearing mineral found in nature. It is generally found as impregnations in mineral veins or fractures, or having replaced quartz in rocks near volcanic or hotspring areas (U.S. Geological Survey, 1970). Economic mercury deposits have not been reported in the Walker River Basin in Lyon and Mineral Counties (Moore, 1969; Ross, 1961); however, during World Wars I and II, almost all of the Nation's mercury production came from the Pilot Mountains in Mineral County (Ross, 1961), which are located outside the Walker River Basin about 40 mi southeast of Walker Lake.

Geothermal springs commonly have high concentrations of trace elements, including mercury and discharge from geothermal springs may be a source of mercury to streams in the study area. Additionally, soils in geothermal areas may be enriched in mercury and erosion of the soils may contribute mercury to surface water bodies. A recent thesis by Thomas (2003) showed that springs in the Steamboat Springs geothermal area, Washoe County, were not the source of mercury to Steamboat Creek, rather the mercury originated in particulate matter derived from erosion of naturally enriched sediment in the area.

Several geothermal springs are present within the Walker River Basin and their locations are shown on plate 1. Several hot springs are located near the Walker River and a large complex of hot springs in the Wabuska area is located 7 to 8 miles to the east of the river. Erosion of soils in areas near hot springs and direct discharge of spring water have the potential to contribute mercury to the Walker River, but the actual contribution of mercury to the river is unknown and cannot be estimated with available data. Only one analysis for mercury in geothermal water from the study area was identified, $<0.5 \mu \mathrm{g} / \mathrm{L}$ from a well near Wabuska (Garside and Schilling, 1979). 


\section{Atmospheric Deposition}

Annual atmospheric deposition of inorganic mercury ranges from about 0.3 to $30 \mu \mathrm{g} / \mathrm{m}^{2}$ and is the primary source of mercury contamination for most aquatic ecosystems (Krabbenhoft and others, 1999). The largest anthropogenic sources of mercury to the atmosphere are coal combustion, waste incineration, and non-ferrous metal smelting.

\section{Ore Deposits and Mining Activities in the Walker River Basin}

Numerous ore deposits within the Walker River Basin (plate 1) could be potential sources of mercury. Mercury is naturally enriched in association with gold deposits and mercury commonly was used during the milling and extraction of gold from the ore. Thus, these ore deposits and milling operations are potential sources of contamination. Major mining districts in the basin include Aurora (gold), Bodie (gold), and Yerington (copper). Many of the larger mills operated on streams that are tributary to the East Fork of the Walker River. Hill (1915) reported several mining operations actively using mercury in amalgamation mills in such locations as Pamlico (20-stamp mill), Pine Grove (15-stamp and 10-stamp mills), and Rockland (20-stamp mill), locations that most likely did not have surface drainage into the Walker River or one of its tributaries and thus, are unlikely sources of mercury to Walker Lake.

\section{Military Activities}

In the past, millions of gallons of water containing munitions was disposed of in open pits at the Hawthorne Army Depot, resulting in a nitrogen contaminant plume moving through the ground towards Walker Lake (Van Denburgh and others, 1996); however, because mercury binds tightly to sediments it is unlikely that any mercury in the munitions would migrate in ground water to the lake. Propellant is burned openly at the depot; however, mercury is not a component of propellants. Mercury fulminate is a component used in primers, percussion caps, blasting caps, and other detonators. From World War II to the early 1970s, the southern tip of Walker Lake was used as an impact area for extensive testing of rockets, mortars, and depth charges (Department of the Army, undated). Thus, military use of mercury in detonators is a potential source of mercury to Walker Lake but not the Walker River.

\section{Methods}

\section{Selection of Sampling Sites}

Water, sediment, and biological samples were collected from streams throughout the basin to characterize changes in mercury concentrations in a downstream direction. Some sites were sampled because of their association with mining activi- ties and their potential to be large contributors of mercury. Water and biological samples were collected from lakes and reservoirs throughout the basin to assess exposure of biota to mercury in water. Cores were collected from lakes and reservoirs throughout the basin to assess exposure of biota to mercury in sediment, and to evaluate temporal changes in mercury contributions to the lakes.

\section{Collection and Analysis of Streambed-Sediment Samples}

Streambed-sediment samples were collected by the USGS using methods described by Shelton and Capel (1994). The collection consisted of obtaining 5 to 10 subsamples of the upper $1 \mathrm{~cm}$ from depositional areas within the stream and compositing these samples into a glass bowl. The composite sample was then homogenized and a subsample placed into a Teflon vial and placed on ice until it could be frozen. Samples were then sent to the USGS mercury research laboratory in Madison, Wisconsin, for analysis of mercury and methylmercury using the methods of Olson and DeWild (1999).

\section{Collection and Analysis of Lake Sediment Cores}

Lake-sediment cores were collected in Bridgeport and Weber Reservoirs, and Topaz and Walker Lakes to determine mercury content. The cores were obtained using a gravity coring device fitted with a polycarbonate liner. Upon retrieval of the sediment core, the plastic liner was removed from the device, the ends of the core were capped, and the core was placed on ice until it was subsampled. Core samples from Bridgeport and Weber Reservoirs, and Topaz Lake, and in six samples from Walker Lake, material from the center portion of the upper $15-\mathrm{cm}$ of the core was homogenized and a subsample of that was analyzed.

Four sediment cores were obtained from Walker Lake during 2000 and 2001 and were subsampled to determine how mercury concentrations change with depth. In three cores collected during 2000, the upper $60 \mathrm{~cm}$ was split into $15-\mathrm{cm}$ intervals and each interval was analyzed. To provide finer detail of the depositional history of mercury in Walker Lake, the $80 \mathrm{~cm}$ core collected during 2001 was split into $4-\mathrm{cm}$ intervals and each interval analyzed.

Sample material was placed in Teflon containers and was immediately frozen before being sent to the USGS mercury research laboratory. The methods of Olson and DeWild (1999) were used for analysis of mercury and methylmercury.

\section{Collection and Analysis of Water Samples}

Water samples were collected from streams and lakes using standard protocols established by the USGS (1998). Stream samples were collected using an equal width increment method and a DH-81 hand sampler with a Teflon collection bottle. Lake samples were pumped from the collection depth with 


\section{Mercury in the Walker River Basin, Nevada and California-Sources, Distribution and Potential Effects on the Ecosystem}

a peristaltic pump and an attached Teflon line directly into the sample bottle. Samples were preserved with hydrochloric acid and sent to the USGS mercury research laboratory for analysis of total mercury using the methods of Olson and DeWild (1999). Samples collected from lakes and reservoirs were also analyzed for methylmercury.

\section{Collection and Analysis of Biotic Samples}

Samples of aquatic invertebrates were collected from streams with a kick net, by fine mesh screen, or by hand using latex gloves in the case of some crayfish. Invertebrates were removed from kick nets by gloved hand or stainless steel forceps and placed in glass jars or stainless steel trays. Small invertebrates were sorted by type and removed from trays with forceps into tared glass jars. Crayfish were sorted by size when sufficient numbers were available and placed in glass jars. Specimens in jars were placed on ice in the field and frozen before sending to the laboratory.

Fish were collected by several methods. Fish from Walker Lake were collected by hook and line in 2000, whereas all fish from the lake were collected with gill nets in 2001. Fish from river sites were collected by seine. Fish were sorted by size and species, measured, and placed into glass jars or clean zip-lock bags. Specimens were placed on ice in the field and frozen before sending to the laboratory.

Kick nets were cleaned with detergent and rinsed with water collected from the site between sampling sites. Forceps and trays were cleaned with detergent and rinsed with dilute acid and de-ionized water between sampling sites.

Composite samples of invertebrates and whole-body fish were analyzed for total mercury. Samples collected in 1999 and 2001 were analyzed by the Patuxent Analytical Control Facility (USFWS, Laurel, Maryland). Samples collected in 1999 were digested with sulfuric and nitric acids (Monk, 1961). Fish samples collected in 2001 were freeze dried and the freeze-dried tissue was digested with nitric acid and hydrogen peroxide. Samples collected in 2000 were analyzed by Environmental Trace Substances Laboratory at the University of Missouri-Rolla. Samples were homogenized and digested with nitric acid and then diluted with hydrochloric acid. The samples were mixed with hydroxylamine for primary reduction and then mixed with stannous chloride for reduction to mercury vapor. Mercury concentrations at both laboratories were measured by cold vapor atomic absorption spectrophotometry.

Loons were captured using night-lighting methods outlined by Evers (2001). Captured individuals were held in cardboard boxes and brought back to shore at a designated station for processing. Blood and feather samples were taken as were various morphometric measurements. Body weight was determined with a $10 \mathrm{~kg}$ Pesola spring scale. Because loons did not yodel (a territorial call only given by the male) and we did not have a known breeding population to estimate the range of sexual dimorphism, the loon's sex was not determined. Processing generally lasted less than 30 minutes, after which the loons were released.
Blood was drawn from the metatarsal vein through a leur adapter directly into 5-10 ml vacutainers containing sodium heparin and placed immediately on ice. Vacutainers were opened once, 10-14 hours later, to add 10 percent buffered formalin (1:20 formalin-blood ratio) using USFWS protocols (Stafford and Stickel, 1981; Wiemeyer and others, 1984). Each time formalin was drawn from the sealed container using a new $1-\mathrm{ml}$ syringe with a measurement precision of $0.02 \mathrm{ml}$. The vacutainer with blood preserved with formalin was then placed in a refrigerator and not opened until it was received at the laboratory. Feathers were clipped at the calamus and placed in a polyethylene bag. Methylmercury is locked in the keratin proteins of the feather and is not subject to degradation (Thompson, 1996). Feathers were clipped again at a standard location at the superior umbilicus and cleaned in the laboratory to remove external contaminants. Lab analyses for mercury in blood and feathers followed Evers and others (1998). Analyses of all blood and feather tissues were conducted by Dr. Robert Poppenga, Animal Health Diagnostics Laboratory, University of Pennsylvania, New Bolton, Pennsylvania.

\section{Age-Dating of Walker Lake Sediment Cores}

Isotopic age-dating techniques were applied to samples of a Walker Lake sediment core collected in 2001. The core of lake sediment was analyzed for excess ${ }^{210} \mathrm{~Pb}$ activity to determine age and sediment accumulation rates for the past 100-150 years. Lead-210 activity was measured in twelve 2-cm sections of the upper part (top $60 \mathrm{~cm}$ ) of the core by ${ }^{210} \mathrm{Po}$-distillation and alpha-spectrometry methods (Eakins and Morrison, 1978) and dates were determined by the constant rate of supply model of Appleby and Oldfield (1978). Cesium-137 activity was measured in several intervals in the upper part of the core by nondestructive gamma spectrometry in an attempt to define a dating marker for the year 1963 .

\section{Distribution of Mercury in the Walker River Basin}

Locations of sample collection sites where water, sediment and biota were collected are shown in figure 1, the location and the identifiers used in this report are shown on plate 1. Common loons were collected at several locations at Topaz and Walker Lakes, with the majority of the loons being collected at the south end of Walker Lake. Water and sediment samples collected by the USGS were commonly within half a mile from the locations where USFWS collected fish and aquatic invertebrate samples. The exact locations for sampling sites can be determined from latitude and longitude values provided in tables 1 , 2 , and 4 . 


\section{Water}

Data on mercury concentrations in water samples collected as part of this investigation are presented in tables 1 and 2 . A total of 15 water samples were collected in 2000-2001 at 11 stream sites and four lake and reservoir sites. Water from several of the tributaries to the Walker River was not analyzed for mercury because the streams were dry when samples were collected in the fall of 2000 and 2001.

Total-mercury concentrations in stream-water samples from the Little Walker River and West Walker River above the confluence with the East Walker River, and the East Walker River and its tributaries above Sonoma Creek (sites 3, 9, 10, 11, 21, 22, and 23; plate 1, table 1) ranged from 0.62 to $5.2 \mathrm{ng} / \mathrm{L}$. The mercury concentration in the East Walker River increased from $1.41 \mathrm{ng} / \mathrm{L}$ at site 23 above Sonoma Creek to nearly $60 \mathrm{ng} / \mathrm{L}$ above the confluence with the West Walker (site 35). Two samples, one from the East Walker River above West Walker River (site 35) and the other from the Walker River above Weber Reservoir (site 37) exceeded $12 \mathrm{ng} / \mathrm{L}$, the Nevada chronic criterion for the protection of freshwater aquatic life (Nevada Bureau of Water Quality Planning, 1998), but were substantially less than the newly recommended chronic criterion of $770 \mathrm{ng} / \mathrm{L}$ (U.S. Environmental Protection Agency, 2002).

For comparison, Fischer and Gustin (2002) showed unfiltered total-mercury concentrations in three uncontaminated mountain streams in the East Fork of the Carson River drainage were 3-4 ng/L during winter and 7-15 $\mathrm{ng} / \mathrm{L}$ at the same sites during the fall. They attributed the seasonal variation to the snowmelt during the winter and inflow of mercury enriched ground water during the fall. Wayne and others (1996), using data from three mountain streams in the Truckee River basin, estimated background total-mercury concentrations for surface water in northwestern Nevada was $<2 \mathrm{ng} / \mathrm{L}$. They also reported mercury concentrations in the Carson River upstream of Carson City were about $3 \mathrm{ng} / \mathrm{L}$. Downstream of Carson City, an area contaminated from ore milling in the late 1800 's, mercury concentrations ranged from 6.6 to $188 \mathrm{ng} / \mathrm{L}$.

Total-mercury concentrations in lake-water samples ranged between $1.02 \mathrm{ng} / \mathrm{L}$ in Topaz Lake and $26.8 \mathrm{ng} / \mathrm{L}$ in Weber Reservoir (table 2). Methylmercury concentrations ranged from $0.056 \mathrm{ng} / \mathrm{L}$ in Walker Lake to $0.429 \mathrm{ng} / \mathrm{L}$ in Topaz Lake. The sample from Weber Reservoir was the only lakewater sample that exceeded $12 \mathrm{ng} / \mathrm{L}$, the Nevada chronic criterion for the protection of freshwater aquatic life (Nevada Environmental Commission, 1991). The total-mercury concentration in Walker Lake was very low, $1.87 \mathrm{ng} / \mathrm{L}$ (site WL5, table 2). Because high $\mathrm{pH}$ and chloride concentrations substantially increase mercury solubility (Hahne and Kroontje, 1973), the low total-mercury concentration was unexpected given the high $\mathrm{pH}(>9)$ and chloride concentrations $(2,000-3,000 \mathrm{mg} / \mathrm{L})$ in Walker Lake (Thodal and Tuttle 1996; Benson and Spencer, 1983). Other low-level mercury analyses for Walker Lake have not been identified. Thodal and Tuttle (1996) reported $<100 \mathrm{ng} / \mathrm{L}$ in two samples collected in 1994 from Walker Lake. For comparison, total-mercury concentrations in Lahontan Reservoir in the mercury contaminated Carson River system ranged from 21 to $977 \mathrm{ng} / \mathrm{L}$ (Wayne and others, 1996; Gustin and others, 1994).

\section{Streambed Sediment and Lake Sediment Cores}

Data on mercury concentrations in streambed-sediment and lake-sediment cores collected as part this study are presented in tables 1 and 2 . The concentration of mercury in sediment provides a better description of the distribution of mercury in the Walker River Basin than water samples because mercury is predominantly found in sediment rather than water and because sediment samples could be collected even if the streams were dry. Total-mercury concentrations in streambed sediment ranged from 1 to $13,600 \mathrm{ng} / \mathrm{g}$ and methylmercury concentrations ranged from 0.07 to $32.1 \mathrm{ng} / \mathrm{g}$ (table 1 ). For comparison, Miller and others (1998) estimated that natural concentrations of mercury in the $<2 \mathrm{~mm}$ size fraction of Carson River sediment were on the order of 10 to $100 \mathrm{ng} / \mathrm{g}$. Gustin and others (1994) reported that total-mercury concentrations ranged from 2,000 to $156,000 \mathrm{ng} / \mathrm{g}$ in contaminated Carson River sediments and had a mean concentration of 27,000 ng/g.

In the West Walker system, total-mercury concentrations in streambed sediment were always less than $100 \mathrm{ng} / \mathrm{g}$ and typically less than $50 \mathrm{ng} / \mathrm{g}$ (sites 2-9; plate 1, table 1). In the East Walker system, mercury concentrations varied greatly. Streambed sediment in the East Walker River below Masonic Gulch (site 23) contained less than $50 \mathrm{ng} / \mathrm{g}$ total mercury but sediment for several tributaries upstream of the site contained more than $100 \mathrm{ng} / \mathrm{g}$. Approximately 5 miles downstream from site 23, mercury concentrations in the East Walker River at site 31 increased to more than $1,000 \mathrm{ng} / \mathrm{g}$, reflecting the input of mercury-contaminated sediment from the Rough Creek drainage. Except for one site (site 36), total-mercury concentrations in sediment on the East Walker and main stem of the Walker River were $100 \mathrm{ng} / \mathrm{g}$ or greater in all sites downstream of the Rough Creek drainage. Total-mercury concentration in bed sediment in Rough Creek (site 30) was $83 \mathrm{ng} / \mathrm{g}$.

The greatest total-mercury concentration in streambed sediment $(13,600 \mathrm{ng} / \mathrm{g})$ was found in Bodie Creek below Bodie (site 25, table 1). This site, and all of the other sites in tributary drainages that contain more than $100 \mathrm{ng} / \mathrm{g}$ total mercury (sites $10,14,17,22,26,27$, and 29), have mines in their headwaters (plate 1). Not all sites with mines in their headwaters have elevated mercury concentrations; sites 15 and 16 have totalmercury concentrations in bed sediment of equal to or less than $60 \mathrm{ng} / \mathrm{g}$. Mercury contamination may have been missed at sites 15 and 16 , or alternatively, the sites may be uncontaminated even though there are mines in their headwaters. 
Table 1. Concentrations of total mercury and methylmercury in water and sediment samples at surface-water sites in the Walker River Basin, 2000-2001

[Abbreviations and symbols: D, dry; ng/g, nanograms per gram; ng/L, nanograms per liter, W, wet; --, data not available or not collected.]

\begin{tabular}{|c|c|c|c|c|c|c|c|c|c|}
\hline \multirow{2}{*}{$\begin{array}{c}\text { Site } \\
\text { identification } \\
\text { (plate 1) }\end{array}$} & \multirow[b]{2}{*}{ Site name } & \multirow[b]{2}{*}{$\begin{array}{c}\text { USGS } \\
\text { station } \\
\text { identification }\end{array}$} & \multirow[b]{2}{*}{ Latitude } & \multirow[b]{2}{*}{$\begin{array}{l}\text { Longi- } \\
\text { tude }\end{array}$} & \multirow[b]{2}{*}{ Date } & \multicolumn{3}{|c|}{ Sediment } & \multirow{2}{*}{$\begin{array}{c}\text { Water } \\
\begin{array}{c}\text { Total } \\
\text { mercury } \\
(\mathrm{ng} / \mathrm{L})\end{array}\end{array}$} \\
\hline & & & & & & $\begin{array}{c}\text { Total } \\
\text { mercury } \\
(\mathrm{ng} / \mathrm{g})^{\mathrm{a}}\end{array}$ & $\begin{array}{l}\text { Methyl } \\
\text { mercury } \\
(\mathrm{ng} / \mathrm{g})^{\mathrm{a}}\end{array}$ & Status $^{b}$ & \\
\hline \multicolumn{10}{|c|}{ West Walker River } \\
\hline 2 & West Walker above Little Walker River & -- & 382224 & 1192712 & $9 / 19 / 00$ & 25 & -- & $\mathrm{W}$ & -- \\
\hline 3 & Little Walker River above West Walker River & 10295500 & 382139 & 1192638 & $9 / 19 / 00$ & 44 & -- & $\mathrm{W}$ & 0.62 \\
\hline 4 & Mill Canyon Creek above Lost Cannon Creek & 10296580 & 382912 & 1192901 & $9 / 18 / 01$ & 8.39 & 0.07 & $\mathrm{~W}$ & -- \\
\hline 5 & Lost Cannon Creek & -- & 382926 & 1192916 & $9 / 18 / 01$ & 14.8 & 0.48 & $\mathrm{~W}$ & -- \\
\hline 6 & West Walker River near Coleville & 10296500 & 383037 & 1192655 & $9 / 22 / 00$ & 17 & -- & $\mathrm{W}$ & -- \\
\hline 7 & West Walker River at Wellington & 10297500 & 384340 & 1192534 & $9 / 22 / 00$ & 23 & -- & $\mathrm{W}$ & -- \\
\hline 9 & West Walker River above East Walker River at ST208 & -- & 385325 & 1191045 & $9 / 18 / 00$ & 95 & 0.54 & $\mathrm{~W}$ & 1.28 \\
\hline \multicolumn{10}{|c|}{ East Walker River Sites } \\
\hline 10 & Virginia Creek near Bridgeport & 10289000 & 381130 & 1191230 & $9 / 19 / 00$ & 148 & -- & $\mathrm{W}$ & 2.72 \\
\hline 11 & Green Creek near Bridgeport & 10289500 & 381025 & 1191400 & $9 / 19 / 00$ & 24 & -- & $\mathrm{W}$ & 0.89 \\
\hline 12 & Robinson Creek near Bridgeport & 10290500 & 381020 & 1191925 & $9 / 20 / 00$ & 1 & -- & $\mathrm{W}$ & -- \\
\hline 13 & Buckeye Creek near Bridgeport & 10291500 & 381420 & 1191930 & $9 / 20 / 00$ & 11 & -- & $\mathrm{W}$ & -- \\
\hline 14 & Frying Pan Creek at East Walker River & -- & 382431 & 1191025 & $9 / 18 / 00$ & 330 & -- & $\mathrm{W}$ & -- \\
\hline 15 & Green Creek above Ferris Ditch & -- & 382602 & 1191317 & $9 / 21 / 00$ & 60 & -- & $\mathrm{W}$ & -- \\
\hline 16 & Ferris Ditch above Green Creek & -- & 382606 & 1191322 & $9 / 21 / 00$ & 47 & -- & $\mathrm{W}$ & -- \\
\hline \multirow[t]{2}{*}{17} & Silverado Canyon Creek below tailings & -- & 382716 & 1191322 & $9 / 21 / 00$ & 132 & -- & $\mathrm{D}$ & -- \\
\hline & & & & & (replicate) & 127 & -- & $\mathrm{D}$ & -- \\
\hline 19 & Silverado Canyon Creek near Sweetwater Creek & -- & 382739 & 1191119 & $9 / 20 / 00$ & 21 & -- & $\mathrm{D}$ & -- \\
\hline 20 & Sweetwater Creek below Silverado Ranch & -- & 382808 & 1191051 & $9 / 21 / 00$ & 67 & -- & $\mathrm{W}$ & \\
\hline 21 & Green Creek above Sweetwater Creek & -- & 382726 & 1191001 & $9 / 20 / 00$ & 36 & -- & $\mathrm{W}$ & -- \\
\hline 22 & Sweetwater Creek at East Walker River & -- & 382620 & 1190745 & $9 / 21 / 00$ & 535 & -- & $\mathrm{W}$ & 0.80 \\
\hline 23 & East Walker River below Masonic Gulch & -- & 382628 & 1190623 & $9 / 21 / 00$ & 46 & -- & $\mathrm{W}$ & 5.20 \\
\hline 24 & Sonoma Creek above East Walker River & -- & 382614 & 1190608 & $9 / 21 / 00$ & 47 & -- & $\mathrm{D}$ & 1.41 \\
\hline 25 & Bodie Creek below Bodie & -- & 381333 & 1185950 & $9 / 18 / 01$ & 13,600 & 32.1 & $\mathrm{~W}$ & -- \\
\hline
\end{tabular}


Table 1. Concentrations of total mercury and methylmercury in water and sediment samples at surface-water sites in the Walker River Basin, 2000-2001-Continued

\begin{tabular}{|c|c|c|c|c|c|c|c|c|c|}
\hline \multirow[b]{2}{*}{$\begin{array}{c}\text { Site } \\
\text { identification } \\
\text { (plate 1) }\end{array}$} & \multirow[b]{2}{*}{ Site name } & \multirow[b]{2}{*}{$\begin{array}{c}\text { USGS } \\
\text { station } \\
\text { identification }\end{array}$} & \multirow[b]{2}{*}{ Latitude } & \multirow[b]{2}{*}{$\begin{array}{l}\text { Longi- } \\
\text { tude }\end{array}$} & \multirow[b]{2}{*}{ Date } & \multicolumn{3}{|c|}{ Sediment } & \multirow{2}{*}{$\begin{array}{c}\text { Water } \\
\begin{array}{c}\text { Total } \\
\text { mercury } \\
\text { (ng/L) }\end{array}\end{array}$} \\
\hline & & & & & & $\begin{array}{c}\text { Total } \\
\text { mercury } \\
(\mathrm{ng} / \mathrm{g})^{\mathrm{a}}\end{array}$ & $\begin{array}{c}\text { Methyl } \\
\text { mercury } \\
(\mathrm{ng} / \mathrm{g})^{\mathrm{a}}\end{array}$ & Status ${ }^{b}$ & \\
\hline \multicolumn{10}{|c|}{ East Walker River Sites--Continued } \\
\hline 26 & Bodie Creek above Del Monte & -- & 381636 & 1185549 & $9 / 18 / 01$ & 464 & 21.8 & $\mathrm{~W}$ & -- \\
\hline 27 & Aurora Creek below Aurora & -- & 381713 & 1185426 & $\begin{array}{c}\text { 9/18/01 } \\
\text { (replicate) }\end{array}$ & $\begin{array}{l}292 \\
471\end{array}$ & $\begin{array}{l}1.95 \\
2.92\end{array}$ & $\begin{array}{l}\mathrm{D} \\
\mathrm{D}\end{array}$ & $\begin{array}{l}-- \\
--\end{array}$ \\
\hline 29 & Bodie Creek below Aurora Creek & -- & 382000 & 1185447 & $9 / 18 / 01$ & 121 & 1.01 & $\mathrm{~W}$ & -- \\
\hline 30 & Rough Creek above East Walker River & -- & 382601 & 1190036 & $9 / 19 / 00$ & 83 & 1.50 & $\mathrm{~W}$ & 11.6 \\
\hline 31 & East Walker River near Aldrich Grade & -- & 382628 & 1190026 & 9/18/01 & 1,040 & 10.7 & & -- \\
\hline 32 & East Walker River below Flying M Ranch & -- & 383524 & 1185959 & $9 / 17 / 01$ & 263 & 2.79 & $\mathrm{~W}$ & -- \\
\hline 33 & East Walker River near Santa Margarita Ranch & -- & 384511 & 1190013 & $\begin{array}{c}9 / 17 / 01 \\
\text { (replicate) }\end{array}$ & $\begin{array}{l}384 \\
442\end{array}$ & $\begin{array}{l}2.86 \\
1.72\end{array}$ & $\begin{array}{l}\text { W } \\
\text { W }\end{array}$ & $\begin{array}{l}-- \\
--\end{array}$ \\
\hline 34 & East Walker River above Mason Valley & -- & 384904 & 1190336 & $9 / 17 / 01$ & 288 & 2.04 & $\mathrm{~W}$ & -- \\
\hline 35 & East Walker River above W Walker River at ST208 & -- & 385322 & 1191002 & $\begin{array}{c}9 / 18 / 00 \\
\text { (replicate) }\end{array}$ & $\begin{array}{l}100 \\
104\end{array}$ & $\begin{array}{l}0.56 \\
0.58\end{array}$ & $\begin{array}{l}\text { W } \\
\text { W }\end{array}$ & $\begin{array}{l}57.11 \\
57.04\end{array}$ \\
\hline \multicolumn{10}{|c|}{ Main Stem Walker River Sites } \\
\hline 36 & Walker River at Wabuska & 10301500 & 390910 & 1190550 & $9 / 18 / 00$ & 57 & -- & $\mathrm{W}$ & 9.99 \\
\hline 37 & Walker River above Weber Res near Schurz & 10301600 & 390604 & 1185537 & $9 / 22 / 00$ & 168 & -- & $\mathrm{W}$ & 14.4 \\
\hline
\end{tabular}

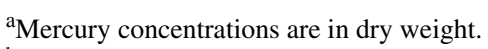

${ }^{b}$ Sediment wet (W) or dry (D) at time of sample collection. 
Table 2. Concentrations of total mercury and methylmercury in water and sediment samples at lake sites in the Walker River Basin, 2000-2001

[Abbreviations and symbols: cm, centimeter; m, meter; ng/g, nanograms per gram; ng/L, nanograms per liter, --, data not available or not collected.]

\begin{tabular}{|c|c|c|c|c|c|c|c|c|c|c|}
\hline \multirow[b]{2}{*}{$\begin{array}{c}\text { Site } \\
\text { identification }\end{array}$} & \multirow[b]{2}{*}{ Location description } & \multirow[b]{2}{*}{ Latitude } & \multirow[b]{2}{*}{$\begin{array}{l}\text { Longi- } \\
\text { tude }\end{array}$} & \multirow[b]{2}{*}{ Date } & \multicolumn{3}{|c|}{ Sediment } & \multicolumn{3}{|c|}{ Water } \\
\hline & & & & & $\begin{array}{c}\text { Core } \\
\text { depth } \\
(\mathrm{cm})\end{array}$ & $\begin{array}{c}\text { Total } \\
\text { mercury } \\
(\mathrm{ng} / \mathrm{g})^{\mathrm{a}}\end{array}$ & $\begin{array}{l}\text { Methyl- } \\
\text { mercury } \\
(\mathrm{ng} / \mathrm{g})^{\mathrm{a}}\end{array}$ & $\begin{array}{c}\text { Total } \\
\text { mercury } \\
(\mathrm{ng} / \mathrm{L})\end{array}$ & $\begin{array}{l}\text { Methyl- } \\
\text { mercury } \\
\text { (ng/L) }\end{array}$ & $\begin{array}{l}\text { Depth } \\
\text { (m) }\end{array}$ \\
\hline \multicolumn{11}{|c|}{ Topaz Lake } \\
\hline TL1 & South of reservoir center & 384032 & 1193224 & $5 / 18 / 00$ & 11.5 & 53 & $\begin{array}{c}6.11 \\
\text { (replicate) }\end{array}$ & $\begin{array}{l}1.02 \\
0.91\end{array}$ & $\begin{array}{l}0.429 \\
0.479\end{array}$ & $\begin{array}{l}15.5 \\
15.5\end{array}$ \\
\hline \multicolumn{11}{|c|}{ Bridgeport Reservoir } \\
\hline BP1 & Near center of reservoir & 381838 & 1191305 & $9 / 18 / 00$ & $2.5-13$ & 6.00 & 0.016 & 2.88 & 0.227 & 0.61 \\
\hline \multicolumn{11}{|c|}{ Weber Reservoir } \\
\hline WR1 & Near delta & 390312 & 1185208 & $9 / 18 / 00$ & $6-13$ & 320 & 0.555 & -- & -- & -- \\
\hline WR2 & South of delta & 390300 & 1185205 & $9 / 18 / 00$ & $4-6$ & 272 & 0.106 & -- & -- & -- \\
\hline WR3 & North of reservoir center & 390252 & 1185144 & $9 / 18 / 00$ & $5-13$ & 377 & 0.315 & -- & -- & -- \\
\hline & & & & & (replicate) & 331 & 0.354 & -- & -- & -- \\
\hline WR4 & Near center of reservoir & 390241 & 1185138 & $9 / 18 / 00$ & $5-13$ & 387 & 0.315 & 26.79 & 0.140 & 0.61 \\
\hline \multicolumn{11}{|c|}{ Walker Lake } \\
\hline \multirow[t]{4}{*}{ WL1 } & Near delta, site \#1 & 384719 & 1184317 & $9 / 19 / 00$ & $0-15$ & 131 & 0.081 & -- & -- & -- \\
\hline & & & & & $15-30$ & 103 & 0.092 & -- & -- & -- \\
\hline & & & & & $30-45$ & 140 & 0.122 & -- & -- & -- \\
\hline & & & & & $45-60$ & 172 & 0.118 & -- & -- & -- \\
\hline WL2 & Near delta, site \#2 & 384703 & 1184248 & $9 / 19 / 00$ & $0-15$ & 8 & -- & -- & -- & -- \\
\hline WL3 & At northeast edge & 384452 & 1184027 & $9 / 19 / 00$ & $0-15$ & 295 & -- & -- & -- & -- \\
\hline \multirow[t]{10}{*}{ WL4 } & At north center & 384336 & 1184301 & $5 / 22 / 01$ & $0-4$ & 993 & 0.703 & -- & -- & -- \\
\hline & & & & & $4-8$ & 450 & 0.409 & -- & -- & -- \\
\hline & & & & & $8-12$ & 200 & 0.199 & -- & -- & -- \\
\hline & & & & & $12-16$ & 207 & 0.120 & -- & -- & -- \\
\hline & & & & & $16-20$ & 188 & 0.094 & -- & -- & -- \\
\hline & & & & & $20-24$ & 317 & 0.155 & -- & -- & -- \\
\hline & & & & & $24-28$ & 432 & 0.186 & -- & -- & -- \\
\hline & & & & & (replicate) & 471 & 0.230 & -- & -- & -- \\
\hline & & & & & (replicate) & -- & 0.181 & -- & -- & \\
\hline & & & & & $28-32$ & 571 & 0.186 & -- & -- & \\
\hline
\end{tabular}


Table 2. Concentrations of total mercury and methylmercury in water and sediment samples at lake sites in the Walker River Basin, 2000-2001-Continued

\begin{tabular}{|c|c|c|c|c|c|c|c|c|c|c|}
\hline \multirow[b]{2}{*}{$\begin{array}{c}\text { Site } \\
\text { identification }\end{array}$} & \multirow[b]{2}{*}{ Location description } & \multirow[b]{2}{*}{ Latitude } & \multirow[b]{2}{*}{$\begin{array}{l}\text { Longi- } \\
\text { tude }\end{array}$} & \multirow[b]{2}{*}{ Date } & \multicolumn{3}{|c|}{ Sediment } & \multicolumn{3}{|c|}{ Water } \\
\hline & & & & & $\begin{array}{l}\text { Core } \\
\text { depth } \\
(\mathrm{cm})\end{array}$ & $\begin{array}{c}\text { Total } \\
\text { mercury } \\
(\mathrm{ng} / \mathrm{g})^{\mathrm{a}}\end{array}$ & $\begin{array}{l}\text { Methyl- } \\
\text { mercury } \\
(\mathrm{ng} / \mathrm{g})^{\mathrm{a}}\end{array}$ & $\begin{array}{c}\text { Total } \\
\text { mercury } \\
\text { (ng/L) }\end{array}$ & $\begin{array}{l}\text { Methyl- } \\
\text { mercury } \\
\text { (ng/L) }\end{array}$ & $\begin{array}{c}\text { Depth } \\
\text { (m) }\end{array}$ \\
\hline \multicolumn{11}{|c|}{ Walker Lake--Continued } \\
\hline \multirow[t]{13}{*}{ WL4 } & At north center & 384336 & 1184301 & $5 / 22 / 01$ & $32-36$ & 998 & 0.277 & -- & -- & -- \\
\hline & & & & & $36-40$ & 1,560 & 0.412 & -- & -- & -- \\
\hline & & & & & $40-44$ & 1,060 & 0.936 & -- & -- & -- \\
\hline & & & & & $44-48$ & 2,660 & 0.612 & -- & -- & -- \\
\hline & & & & & $48-52$ & 348 & 0.248 & -- & -- & -- \\
\hline & & & & & $52-56$ & 110 & 0.509 & -- & -- & -- \\
\hline & & & & & $56-60$ & 35.8 & 0.133 & -- & -- & -- \\
\hline & & & & & (replicate) & 36.0 & 0.123 & -- & -- & -- \\
\hline & & & & & $60-64$ & 63.8 & 0.073 & -- & -- & -- \\
\hline & & & & & $64-68$ & 33.7 & 0.014 & -- & -- & -- \\
\hline & & & & & $68-72$ & 26.9 & 0.053 & -- & -- & -- \\
\hline & & & & & $72-76$ & 27.0 & -- & -- & -- & -- \\
\hline & & & & & $76-80$ & 23.8 & 0.010 & -- & -- & -- \\
\hline \multirow[t]{4}{*}{ WL5 } & Near center & 384326 & 1184304 & $9 / 19 / 00$ & $0-15$ & 418 & 0.241 & 1.87 & 0.056 & 0.61 \\
\hline & & & & & $15-30$ & 1099 & 1.374 & -- & -- & -- \\
\hline & & & & & $30-45$ & 37 & 0.141 & -- & -- & -- \\
\hline & & & & & $45-60$ & 31 & 0.035 & -- & -- & -- \\
\hline WL6 & Near Sportsman Beach & 384057 & 1184535 & $9 / 19 / 00$ & $0-15$ & 361 & 0.357 & -- & -- & -- \\
\hline \multirow[t]{4}{*}{ WL7 } & At southeast edge & 383952 & 1184132 & $9 / 26 / 00$ & $0-15$ & 326 & 0.234 & -- & -- & -- \\
\hline & & & & & $15-30$ & 1205 & 1.468 & -- & -- & -- \\
\hline & & & & & $30-45$ & 41 & 0.075 & -- & -- & -- \\
\hline & & & & & $45-60$ & 31 & 0.062 & -- & -- & -- \\
\hline WL8 & Near town of Walker Lake & 383935 & 1184429 & $9 / 19 / 00$ & $0-15$ & 387 & 0.116 & -- & -- & -- \\
\hline WL9 & At south central part of lake & 383842 & 1184236 & $9 / 26 / 00$ & $0-15$ & 418 & 0.333 & -- & -- & -- \\
\hline WL10 & At southwest end & 383733 & 1184229 & $9 / 26 / 00$ & $0-15$ & 215 & 0.065 & -- & -- & -- \\
\hline
\end{tabular}

${ }^{\mathrm{a}}$ Mercury concentrations are in dry weight. 
Total-mercury concentrations in near-surface sediment samples $(<15 \mathrm{~cm})$ from Bridgeport Reservoir, $(6 \mathrm{ng} / \mathrm{g})$, and Topaz Lake, $(53 \mathrm{ng} / \mathrm{g})$, were substantially less than those in samples from Weber Reservoir. The average mercury content of the four sites in Weber Reservoir was $339 \mathrm{ng} / \mathrm{L}$ (range 272 to $387 \mathrm{ng} / \mathrm{g}$; table 2). Weber Reservoir is the first reservoir downstream of $19^{\text {th }}$ century mining activities in the Rough Creek drainage, and the elevated mercury levels are thus not surprising.

Sediment cores were taken from nine sites on Walker Lake in 2000 and analyzed for mercury content (table 2). At six sites (WL2, WL3, WL6, WL8, WL9, and WL10; plate 1) mercury concentrations were determined in only the upper $15 \mathrm{~cm}$. Cores from sites WL1, WL5, and WL7 were subsampled at intervals of $15 \mathrm{~cm}$ to determine how mercury concentrations changed with depth (fig. 2). The upper $15 \mathrm{~cm}$ of two cores near the delta (sites WL1 and WL2; plate 1) had total-mercury concentrations of 8 and $131 \mathrm{ng} / \mathrm{g}$; the remaining seven cores had total-mercury concentrations ranging from 215 to $418 \mathrm{ng} / \mathrm{g}$ in the upper $15 \mathrm{~cm}$.

Plots of mercury concentration with depth (fig. 2) show little variation in mercury concentration with depth at site WL1 (plate 1), where concentrations ranged from 103 to $172 \mathrm{ng} / \mathrm{g}$. This core was taken in a location near the delta where the Walker River enters the lake and most likely has a much higher sedimentation rate than the locations of the other two cores. The profiles for the other two cores collected in 2000 (sites WL5 and WL7; plate 1) show maximum mercury concentrations of 1,100 and $1,200 \mathrm{ng} / \mathrm{g}$, respectively, in the $15-30 \mathrm{~cm}$ interval. In contrast, the mercury concentrations beneath these elevated concentrations ranged from 31 to $41 \mathrm{ng} / \mathrm{g}$.

A tenth core was taken from Walker Lake in 2001 (site WL4; plate 1) and subsampled at smaller intervals of $4 \mathrm{~cm}$ to better understand the depositional history of mercury in the lake. At the top of the core, the mercury concentration was almost 1,000 ng/g and decreased to about $200 \mathrm{ng} / \mathrm{g}$ from 8 to $20 \mathrm{~cm}$ depth. In general, concentrations of total mercury increased from $20 \mathrm{~cm}$ until they peaked $(2,660 \mathrm{ng} / \mathrm{g})$ in the $44-48 \mathrm{~cm}$ interval. Below this depth, the mercury concentrations were greatly reduced. Between 64 and $80 \mathrm{~cm}$, mercury concentrations leveled out at values between 20 and $35 \mathrm{ng} / \mathrm{g}$, which most likely represents background mercury concentrations for the Walker River Basin.

A plot of total mercury and methylmercury concentrations for streambed sediment and lake cores (fig. 3) shows that, for a given amount of total mercury, streambed sediment samples tend to contain more methylmercury than do lake core samples. This observation may be related to the presence of reduced sulfur $\left(\mathrm{S}^{-2}\right)$ in the anaerobic lake cores. At high $\mathrm{S}^{-2}$ levels, charged mercuric-sulfide species (for example, $\mathrm{HgSH}^{+}$, $\mathrm{HgS}_{2} \mathrm{H}^{-}, \mathrm{HgS}_{2}^{-2}$ ) form. Smaller amounts of inorganic mercury may be methylated in anaerobic settings because the charged species do not readily cross cell membranes of mercury methylating bacteria (Benoit and others, 1999).
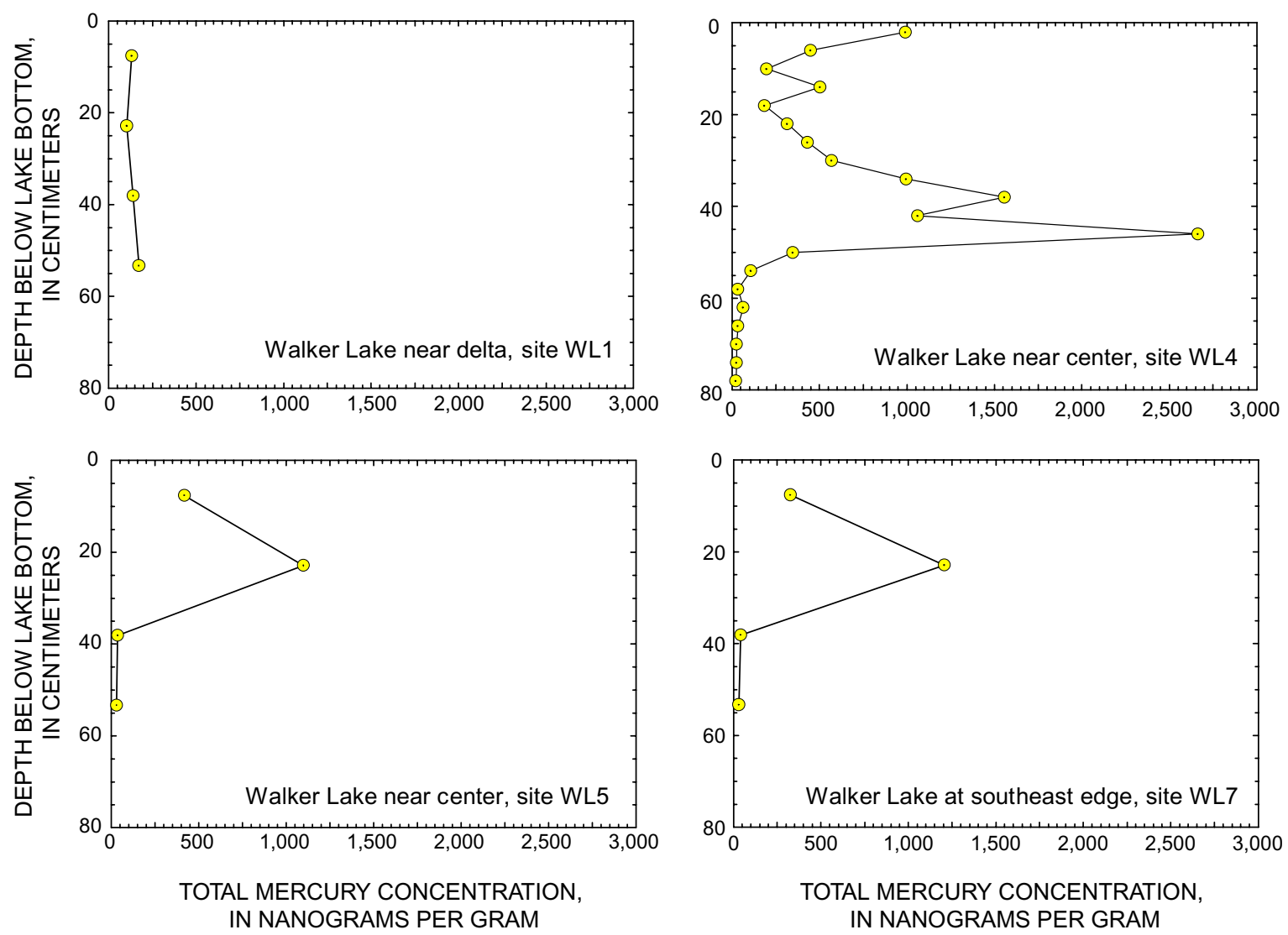

Figure 2. Graphs showing total-mercury concentrations in sediment as a function of depth in Walker Lake, Nevada. 


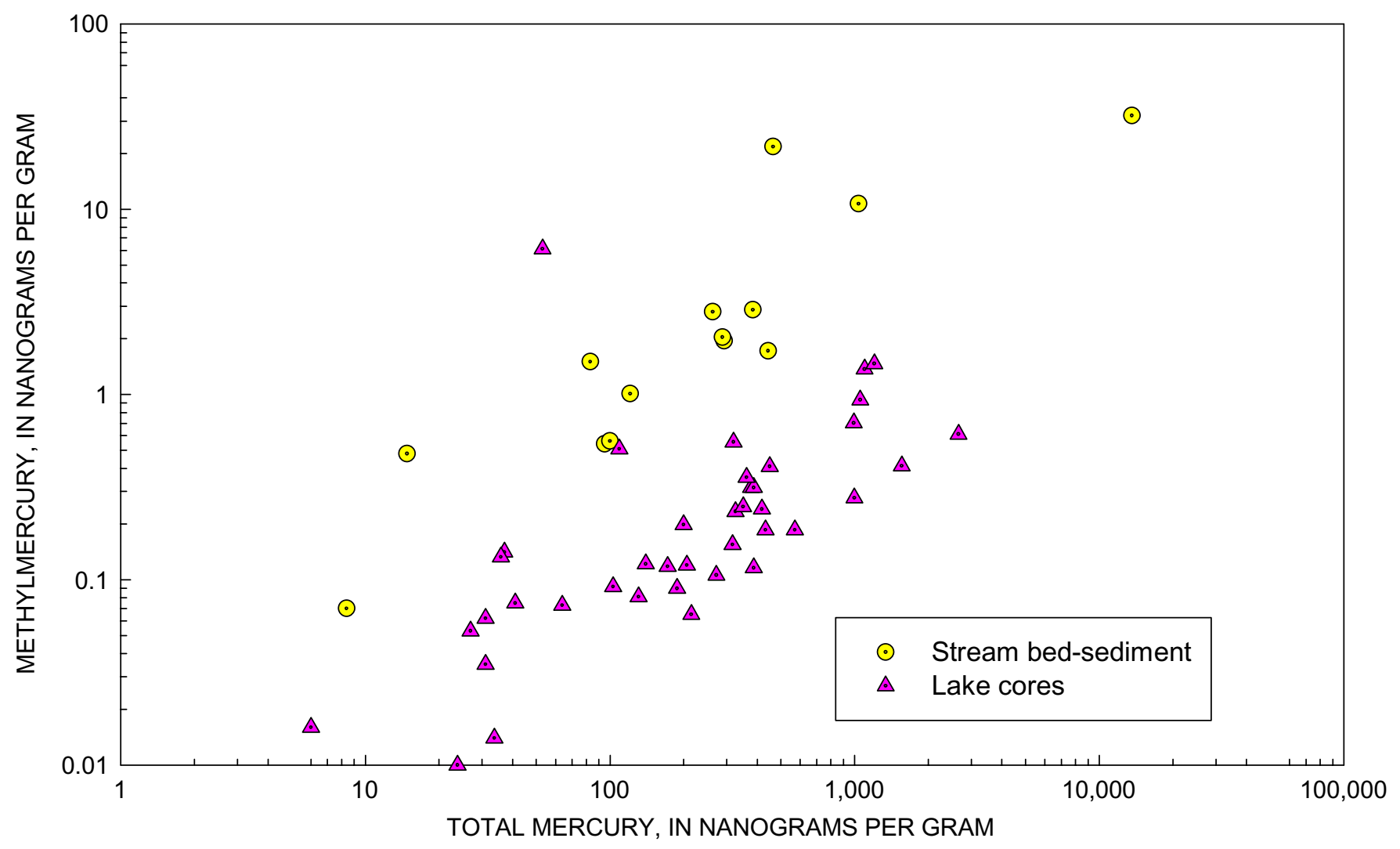

Figure 3. Graph showing relation between total-mercury and methylmercury concentrations in streambed-sediment and lake-sediment core samples from Walker Lake, Nevada

\section{Historical Deposition of Mercury in Walker Lake}

Cores of lake sediment have been used to determine historical deposition of mercury in several locations (Engstrom and Swain, 1997; Kamman and Engstrom, 2002). Many investigators have used sediment cores from lakes and reservoirs to determine atmospheric input of mercury on global scales (Fitzgerald and others, 1998; Swain and others, 1992). Other studies have used sediment cores to determine transport of mercury associated with mining activities to lakes and reservoirs (Hoffman and Taylor, 1998).

Isotopic dating techniques were used on the sediment core from site WL4 (plate 1) to determine the age and deposition rates of sediment at the core site. Lead-210 and ${ }^{137} \mathrm{Cs}$ activities were measured in several subsamples of the core at 2-cm intervals (table 3). Unfortunately, the activities of unsupported ${ }^{210} \mathrm{~Pb}$ were too low, very close to the background (supported ${ }^{210} \mathrm{~Pb}$ ), to accurately date the depositional history of the core with this method. Cesium-137 activities were measured in the upper part of the core. The activities of ${ }^{137} \mathrm{Cs}$ were lower than those commonly found in North America; however, even the low activities of ${ }^{137} \mathrm{Cs}$ can be useful in determining a rate of deposition at the core site. A distinct ${ }^{137} \mathrm{Cs}$ peak was not seen in the core, but the presence of ${ }^{137} \mathrm{Cs}$ to a depth of $8 \mathrm{~cm}$ in the core indicates the upper $8 \mathrm{~cm}$ was deposited after about 1963 .
Table 3. Activities of lead-210 and cesium-137 in sediment cores from site WL4, Walker Lake, Nevada

[Abbreviations and symbols: $\mathrm{cm}$, centimeter; ND, not detected; pCi/g, picocuries per gram; --, not analyzed; \pm , plus/minus standard deviation]

\begin{tabular}{ccc}
\hline $\begin{array}{c}\text { Interval } \\
\text { depth } \\
(\mathbf{c m})\end{array}$ & $\begin{array}{c}\text { Lead-210 } \pm \text { counting } \\
\text { error } \\
\mathbf{( p C i / g )}\end{array}$ & $\begin{array}{c}\text { Cesium-137 } \pm \text { counting } \\
\text { error } \\
\text { (pCi/g) }\end{array}$ \\
\hline $0-2$ & $1.909 \pm 0.032$ & $0.133 \pm 0.060$ \\
$2-4$ & -- & $0.182 \pm 0.018$ \\
$4-6$ & $1.308 \pm 0.023$ & $0.060 \pm 0.014$ \\
$6-8$ & $1.454 \pm 0.080$ & Trace \\
$8-10$ & $1.469 \pm 0.032$ & ND \\
& $1.491 \pm 0.030$ & ND \\
$12-14$ & $1.379 \pm 0.029$ & ND \\
$16-18$ & $1.360 \pm 0.029$ & ND \\
$20-22$ & $1.195 \pm 0.026$ & ND \\
$24-26$ & $1.318 \pm 0.027$ & ND \\
$28-30$ & & \\
& $1.186 \pm 0.037$ & ND \\
$36-38$ & $1.297 \pm 0.037$ & ND \\
$44-46$ & $1.241 \pm 0.040$ & ND \\
$52-54$ & $1.202 \pm 0.028$ & ND \\
$58-60$ & & \\
\hline
\end{tabular}




\section{Mercury in the Walker River Basin, Nevada and California-Sources, Distribution and Potential Effects on the Ecosystem}

The mercury peak in the core from site WL4 at about $46 \mathrm{~cm}$ depth most likely represents the peak of mining and gold extraction in the Bodie and Aurora mining districts. The peak of production in these two districts was between 1870 and 1880 . Thus, a good approximation of the date in the core that corresponds with the large increase in mercury concentration is about 1880. Another important time in the chronology of sedimentation in Walker Lake is the construction of three reservoirs on the East and West Forks and mainstem of the Walker River.

The reservoirs upstream of Walker Lake would affect sedimentation in Walker Lake in two ways. First, the reservoirs act as efficient sediment traps and thus the amount of sediment delivered to Walker Lake is reduced. Secondly, the timing of flows that reach Walker Lake are different than the normal spring flush that is present in an unregulated river. The high spring flows tend to have a higher sediment carrying capacity and thus would deliver more sediment to the lake. Both of these factors would contribute to a greatly different rate of sedimentation in Walker Lake after the reservoirs were in place.

For the purpose of calculating a sedimentation rate for core site WL-4 in Walker Lake, two separate rates are assumed, one after construction of Weber Reservoir in 1934 and one before 1934. The sedimentation rate after $1934,0.21 \mathrm{~cm} / \mathrm{yr}$, was calculated from the amount of sediment $(8 \mathrm{~cm})$ present above the last detected ${ }^{137} \mathrm{Cs}$ in the core (representing 1963 to 2001 or 38 years). Thus, using this rate, the depth of the core that corresponds to 1934 is approximately $14 \mathrm{~cm}$. The sedimentation rate for the pre-1934 part of the core was estimated by assuming that the peak mercury concentration at $44-48 \mathrm{~cm}$ corresponds with the peak mining period in 1880 . The sedimentation rate for the pre-1934 part of the core, $0.59 \mathrm{~cm} / \mathrm{yr}$, was calculated using the amount of sediment deposited from 1880 to $1934(46 \mathrm{~cm}$ and $14 \mathrm{~cm}$, respectively) and the number of years between those dates (54 years).

\section{Mercury in Biota}

Data on mercury concentrations in invertebrate and fish samples collected as part of this study are presented in table 4 . A total of 13 fish and 29 aquatic invertebrate samples were collected during 1999-2001 from nineteen sites. Fish were collected at only two stream sites and at Walker Lake. Fish collected at Walker Lake in 2001 were selected to represent the size of fish believed to be primary food items for common loons (between 10 and $20 \mathrm{~cm}$ total length).

\section{Aquatic Invertebrates}

Total-mercury concentrations in aquatic invertebrates generally were low at data collection sites with no or little evidence of upstream mining activities. At sites 1, 3, 6, 12, and 13, where no evidence of mining upstream was noted based on an examination of topographic maps, mercury concentrations in invertebrates were usually less than $0.08 \mu \mathrm{g} / \mathrm{g}$ (dry weight), and ranged from 0.061 to $0.123 \mu \mathrm{g} / \mathrm{g}$ (table 4 ); however, at site 11 there was no evidence of mining upstream and the mercury concentration in a stonefly sample was elevated $(0.324 \mu \mathrm{g} / \mathrm{g})$. Except for one crayfish sample from site 9 , mercury concentrations in all aquatic-invertebrate samples from the West Walker drainage were less than $0.2 \mu \mathrm{g} / \mathrm{g}$. Total-mercury concentrations in aquatic invertebrates at sites above the confluence of Rough Creek and East Walker River were also less than $0.2 \mu \mathrm{g} / \mathrm{g}$ except for site 11. These values are similar to values for crayfish samples (Lawrence, 1998) and stonefly samples (Fischer and Gustin, 2002) collected in the East Fork of the Carson River watershed above historic gold and silver mining activities in the Carson River basin. Total-mercury concentrations in composite samples of crayfish from two sites along the East Fork were 0.2 and $0.5 \mu \mathrm{g} / \mathrm{g}$ (Lawrence, 1998). Total-mercury concentrations in composite samples of stoneflies from three mountain streams in the same general area ranged from 0.024 to $0.585 \mu \mathrm{g} / \mathrm{g}$ (Fischer and Gustin, 2002).

Sites located downstream from mining activities in the Rough Creek watershed (sites 28, 29, 30, and 36) show aquatic invertebrates with elevated mercury concentrations (ranging from 0.263 to $0.863 \mu \mathrm{g} / \mathrm{g}$; table 4$)$. Out of all of these sites, the mercury concentration in at least one sample of aquatic invertebrates exceeded $0.4 \mu \mathrm{g} / \mathrm{g}$. For comparison, total-mercury concentrations in composite samples of crayfish from two sites on the Carson River downstream of mining activities were 1.9 and $48 \mu \mathrm{g} / \mathrm{g}$ (Lawrence, 1998).

\section{Fish}

Fish were collected at only two stream sites (sites 9 and 36, plate 1). The average mercury concentration for two samples of the Tahoe Sucker (Catostomus tahoensis) from site 9 was 0.081 $\mu \mathrm{g} / \mathrm{g}$ wet weight (table 4 ). The mercury concentration in a black bullhead (Ictalurus melas) sample collected at site 36 in 2000 $(0.03 \mu \mathrm{g} / \mathrm{g}$ wet weight; table 4$)$ was much lower than what was found in the same species at that site in $1994(0.67 \mu \mathrm{g} / \mathrm{g}$ wet weight; Thodal and Tuttle, 1996). The mercury concentration in a sample of largemouth bass (Micropterus salmoides) from the Walker River near Wabuska (site 36) was similar to those collected from the river near Shurz in 1994 for this species (Thodal and Tuttle, 1996). Size information for the 1994 samples is not known, so direct comparisons of mercury concentrations cannot be made.

Mercury concentrations in tui chub (Gila bicolor) from Walker Lake show an abrupt change, with large fish tending to have higher concentrations than small fish (fig. 4). Mercury concentrations were consistently lower $(<0.25 \mu \mathrm{g} / \mathrm{g}$ wet weight $)$ in fish up to $20 \mathrm{~cm}$ in length (mixed total and fork length, and both whole fish and possible fillets). Mercury concentrations exceeded $0.75 \mu \mathrm{g} / \mathrm{g}$ in most tui chub samples greater than $25 \mathrm{~cm}$. The smaller fish are most likely those consumed by common loons; however, male loons average 28 percent larger than females (Evers, 2001) and, therefore, generally consume larger fish (Evers and others, 2003a). Koch and others (1979) indicated that tui chub in Walker Lake are omnivorous and opportunistic in their food habits; a large female ( $32.4 \mathrm{~cm}$ long) 
had remains of young tui chub in its stomach. Wiener and others (2003) reported that mercury accumulation in fish can increase with age, with an abrupt increase when fish switch from an invertebrate diet to a fish diet. A change in food habit at a length of about $25 \mathrm{~cm}$ may explain the large variation in mercury content of tui chub in this size class.

Mercury concentrations were less than $0.03 \mu \mathrm{g} / \mathrm{g}$ (wet weight) in juvenile Lahontan cutthroat trout at site 39 in Walker Lake in 2001 (table 4). These fish are raised in hatcheries and the juvenile fish did not have ample time to accumulate mercury. Larger fish $(33-44 \mathrm{~cm})$ of this species collected in 1995 contained 0.18 to $0.38 \mu \mathrm{g} / \mathrm{g}$ mercury (wet weight; Department of the Army, undated).

\section{Birds}

Blood samples collected from 94 common loons staging at Walker Lake between 1998 and 2001, contained a mean mercury concentration of $2.96 \mu \mathrm{g} / \mathrm{g}$ (wet weight) (standard deviation $1.72 \mu \mathrm{g} / \mathrm{g}$; table 5). Feather samples from 93 of the 94 loons contained a mean concentration of $19.9 \mu \mathrm{g} / \mathrm{g}$ (fresh weight; standard deviation $20.5 \mu \mathrm{g} / \mathrm{g}$; table 5). The mean mercury concentrations in blood and feathers from two common loons at Topaz Lake, a neighboring waterbody, were substantially lower (table 5). For comparison, the North American mean level was $1.72 \mu \mathrm{g} / \mathrm{g}(\mathrm{n}=380$, Evers and others, 1998). Sampling efforts documented record highs for both blood $(9.46 \mu \mathrm{g} / \mathrm{g}$, wet weight) and feather $(131.0 \mu \mathrm{g} / \mathrm{g}$, fresh weight) mercury levels. These levels are substantially higher than those found in over 1,600 adult common loons tested across North America (Evers and others, 1998; Evers, D.C., BioDiversity Research Institute, written commun., 2003).

Larger loons (more than $4 \mathrm{~kg}$ ) had significantly greater blood mercury concentrations $(\mathrm{p}<0.001)$ than did smaller loons (table 5, fig. 5); the broad variability in this relation likely was due to (1) the length of time the loon was foraging on the lake and (2) the ratio of tui chub prey above and below $20 \mathrm{~cm}$. Loons weighing more than $4 \mathrm{~kg}$ (likely males) had average blood mercury concentrations of 77 percent higher than loons weighing less than $4 \mathrm{~kg}$ (most likely females). Since males average 28 percent larger than females within a breeding cohort (Evers and others, 2003a), they are probably exposed to a higher level of mercury in prey and are therefore at greater risk to effects of mercury than females.

According to risk assessments conducted for northeastern North America, common loon blood and feather mercury levels exceeding $3.0 \mu \mathrm{g} / \mathrm{g}$ (wet weight) and $20.0 \mu \mathrm{g} / \mathrm{g}$ (fresh weight) respectively, cause behavioral, reproductive, and physiological effects (Meyer and others, 1998; Burgess and others, 1998; Evers and others, 1998, 2003a, b). Based on blood sampling, at least 52 percent of the loons at Walker Lake are at risk for adverse effects from mercury; 75 percent of the loons, larger than $4 \mathrm{~kg}$, are at risk. Feather sampling efforts for mercury indicate a 27 percent risk level that, unlike blood, is independent of

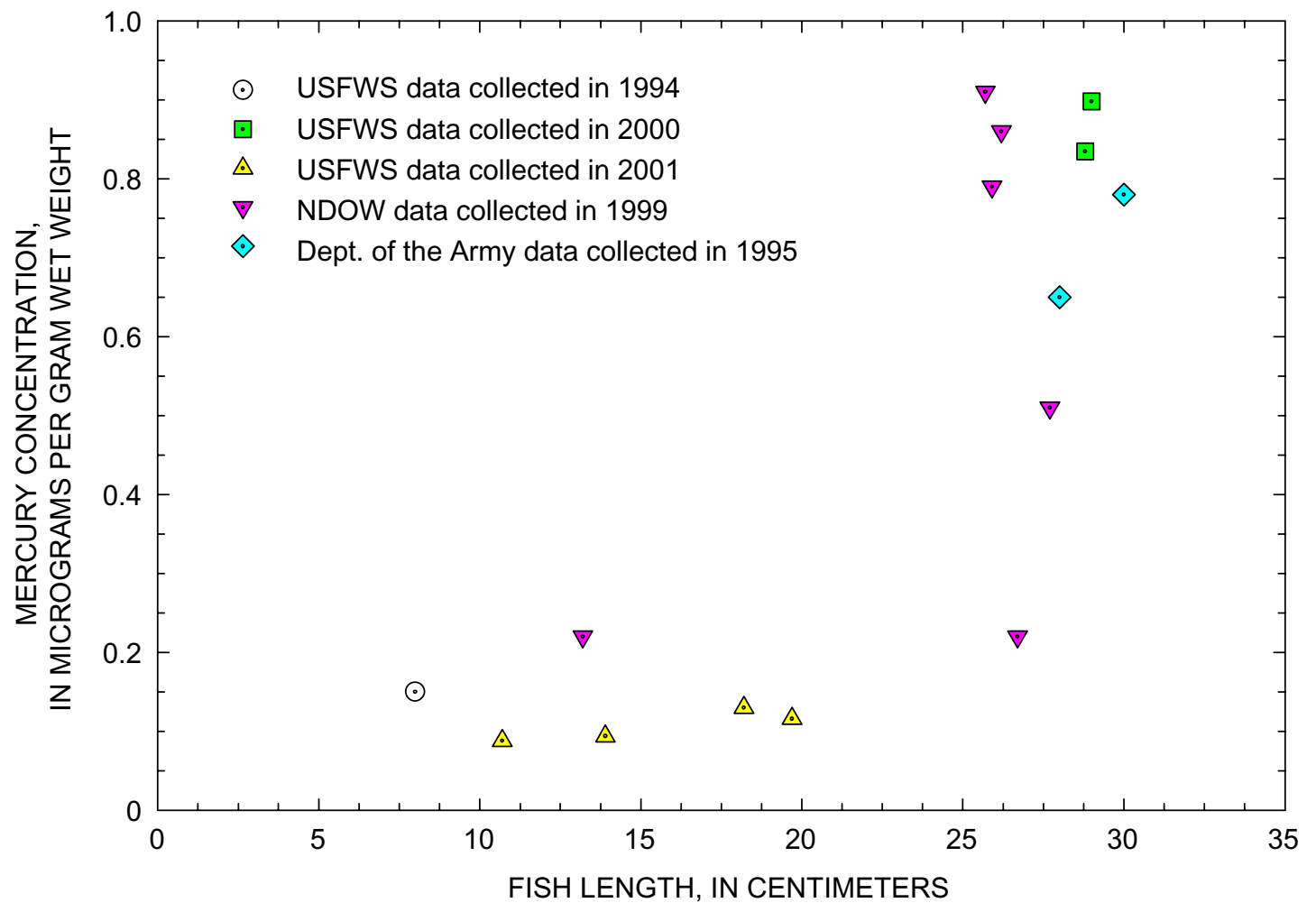

Figure 4. Graph showing relation between fish length and mercury concentration in tui chub from Walker Lake, Nevada. Fish length are a mixture of total and fork lengths. U.S. Fish and Wildlife Service data are for whole fish; samples are composites with several fish in each sample; lengths are means for the pooled samples. Nevada Department of Wildlife data are for whole individual fish. Army data may be for fillets, but that is uncertain; samples are composites; lengths are means for pooled samples. 

per gram; WW, wet weight; --, not applicable; <, less than.]

\begin{tabular}{|c|c|c|c|c|c|c|c|c|c|c|}
\hline \multirow{2}{*}{$\begin{array}{c}\text { Site } \\
\text { identi- } \\
\text { fication }\end{array}$} & \multirow{2}{*}{ Site name } & \multirow{2}{*}{$\begin{array}{l}\text { Lati- } \\
\text { tude }\end{array}$} & \multirow{2}{*}{$\begin{array}{l}\text { Longi- } \\
\text { tude }\end{array}$} & \multirow{2}{*}{ Date } & \multirow{2}{*}{ Species } & \multirow{2}{*}{ Age } & \multirow{2}{*}{$\begin{array}{c}\text { Average } \\
\text { length } \\
(\mathrm{cm})\end{array}$} & \multirow{2}{*}{$\begin{array}{l}\text { Average } \\
\text { weight } \\
\text { (g) }\end{array}$} & \multicolumn{2}{|c|}{$\begin{array}{l}\text { Total mercury } \\
(\mu \mathbf{g} / \mathbf{g})\end{array}$} \\
\hline & & & & & & & & & DW & WW \\
\hline \multicolumn{11}{|c|}{ West Walker River } \\
\hline 1 & West Fork Walker River above Little Walker River & 382158 & 1192847 & $9 / 28 / 00$ & Stonefly & $\mathrm{L}$ & -- & -- & 0.061 & 0.009 \\
\hline 3 & Little Walker River above West Walker River & 382201 & 1192634 & $9 / 28 / 00$ & Stonefly & $\mathrm{L}$ & -- & -- & 0.123 & 0.020 \\
\hline 6 & West Walker River at Walker & & & $9 / 28 / 00$ & Stonefly & $\mathrm{L}$ & -- & -- & 0.122 & 0.016 \\
\hline \multirow[t]{2}{*}{8} & West Walker River at Wellington & 383050 & 1192658 & $9 / 28 / 00$ & Stonefly & $\mathrm{L}$ & -- & -- & 0.077 & 0.014 \\
\hline & & 384536 & 1192250 & $9 / 26 / 00$ & Crayfish & A & -- & 21.1 & 0.106 & 0.023 \\
\hline \multirow[t]{5}{*}{9} & West Walker River above conf with East Walker River & 385322 & 1191042 & $9 / 25 / 00$ & Crayfish & A & -- & 31.2 & 0.326 & 0.083 \\
\hline & & & & $9 / 25 / 00$ & Crayfish & A & -- & 17.5 & 0.159 & 0.036 \\
\hline & & & & $9 / 25 / 00$ & Crayfish & M & -- & 11.1 & 0.133 & 0.029 \\
\hline & & & & $9 / 25 / 00$ & Tahoe Sucker & $\mathrm{J}$ & 5.3 & 1.6 & 0.423 & 0.092 \\
\hline & & & & $9 / 25 / 00$ & Tahoe Sucker & $\mathrm{J}$ & 5.3 & 1.6 & 0.309 & 0.069 \\
\hline \multicolumn{11}{|c|}{ East Walker River } \\
\hline \multirow[t]{2}{*}{10} & Virginia Creek, South of Bridgeport & 381128 & 1191224 & $9 / 27 / 00$ & Stonefly & $\mathrm{L}$ & -- & -- & 0.197 & 0.022 \\
\hline & & & & $9 / 27 / 00$ & Crayfish & $\mathrm{J}$ & -- & 1.0 & 0.182 & 0.039 \\
\hline 11 & Green Creek, south of Bridgeport & 381024 & 1191357 & $9 / 27 / 00$ & Stonefly & $\mathrm{L}$ & -- & -- & 0.324 & 0.044 \\
\hline \multirow[t]{5}{*}{12} & Robinson Creek, south of Bridgeport & 381019 & 1191926 & $9 / 27 / 00$ & Crayfish & A & -- & 30.3 & 0.094 & 0.023 \\
\hline & & & & $9 / 27 / 00$ & Crayfish & A & -- & 16.7 & 0.067 & 0.017 \\
\hline & & & & $9 / 27 / 00$ & Crayfish & $\mathrm{J}$ & -- & 3.9 & 0.064 & 0.014 \\
\hline & & & & $9 / 27 / 00$ & Stonefly & $\mathrm{L}$ & -- & -- & 0.066 & 0.014 \\
\hline & & & & $9 / 27 / 00$ & Stonefly & $\mathrm{L}$ & -- & -- & 0.072 & 0.010 \\
\hline \multirow[t]{2}{*}{13} & Buckeye Creek, west of Bridgeport & 381418 & 1191951 & $9 / 27 / 00$ & Caddisfly & $\mathrm{L}$ & -- & -- & 0.067 & 0.006 \\
\hline & & & & $9 / 27 / 00$ & Stonefly & $\mathrm{L}$ & -- & -- & 0.064 & 0.011 \\
\hline 18 & Green Creek above Sweetwater Creek & 382705 & 1191140 & $9 / 26 / 00$ & Stonefly & $\mathrm{L}$ & -- & -- & 0.025 & 0.006 \\
\hline \multirow[t]{3}{*}{23} & East Walker River below Masonic Gulch & 382628 & 1190621 & $9 / 26 / 00$ & Stonefly & $\mathrm{L}$ & -- & -- & 0.135 & 0.036 \\
\hline & & & & $9 / 26 / 00$ & Dragonfly & $\mathrm{L}$ & -- & -- & 0.102 & 0.012 \\
\hline & & & & $9 / 26 / 00$ & Crayfish & M & -- & 23.7 & 0.149 & 0.038 \\
\hline 28 & Aurora Creek above Bodie Creek & 381743 & 1185538 & 4/14/99 & Caddisfly & $\mathrm{L}$ & -- & -- & 0.498 & 0.067 \\
\hline \multirow[t]{3}{*}{29} & Bodie Creek below Aurora Creek & 382004 & 1185438 & $4 / 14 / 99$ & Crane fly & $\mathrm{L}$ & -- & -- & 0.863 & 0.125 \\
\hline & & & & $4 / 02 / 99$ & Stonefly & $\mathrm{L}$ & -- & -- & 0.263 & 0.058 \\
\hline & & & & $4 / 14 / 99$ & Stonefly & $\mathrm{L}$ & -- & -- & 0.302 & 0.057 \\
\hline 30 & Rough Creek above East Walker River & 382603 & 1190038 & $4 / 02 / 99$ & Crane fly & $\mathrm{L}$ & -- & -- & 0.415 & 0.046 \\
\hline
\end{tabular}


Table 4. Concentrations of total mercury in invertebrate and fish samples from the Walker River Basin, Nevada, 1999-2001-Continued

\begin{tabular}{|c|c|c|c|c|c|c|c|c|c|c|}
\hline \multirow{2}{*}{$\begin{array}{c}\text { Site } \\
\text { identi- } \\
\text { fication }\end{array}$} & \multirow{2}{*}{ Site name } & \multirow{2}{*}{$\begin{array}{l}\text { Lati- } \\
\text { tude }\end{array}$} & \multirow{2}{*}{$\begin{array}{l}\text { Longi- } \\
\text { tude }\end{array}$} & \multirow{2}{*}{ Date } & \multirow{2}{*}{ Species } & \multirow{2}{*}{ Age } & \multirow{2}{*}{$\begin{array}{l}\text { Average } \\
\text { length } \\
(\mathrm{cm})\end{array}$} & \multirow{2}{*}{$\begin{array}{c}\text { Average } \\
\text { weight } \\
(g)\end{array}$} & \multicolumn{2}{|c|}{$\begin{array}{l}\text { Total mercury } \\
(\mu \mathbf{g} / \mathbf{g})\end{array}$} \\
\hline & & & & & & & & & DW & wW \\
\hline \multicolumn{11}{|c|}{ Main Stem Walker River } \\
\hline \multirow[t]{5}{*}{36} & Walker River near Wabuska & 390910 & 1190553 & $9 / 25 / 00$ & Crayfish & $\mathrm{J}$ & -- & 3.3 & 0.472 & 0.104 \\
\hline & & & & $9 / 25 / 00$ & Crayfish & A & -- & 29.3 & 0.552 & 0.134 \\
\hline & & & & $9 / 25 / 00$ & Black bullhead & $\mathrm{S}$ & 17.5 & 66.4 & 0.131 & 0.030 \\
\hline & & & & $9 / 25 / 00$ & Largemouth bass & $\mathrm{J}$ & 9.9 & 14.2 & 1.57 & 0.363 \\
\hline & & & & $9 / 25 / 00$ & Carp & $\mathrm{J}$ & 10.1 & 16.7 & 1.40 & 0.286 \\
\hline \multicolumn{11}{|c|}{ Walker Lake } \\
\hline 38 & North shore near reservation & 384623 & 1184446 & $6 / 02 / 00$ & Tui chub & A & 29 & 307 & 3.17 & 0.898 \\
\hline 39 & West shore near Tufa Point & 384223 & 1184545 & $5 / 17 / 01$ & $\mathrm{LCT}$ & $\mathrm{J}$ & 19.5 & 63.6 & $<0.132$ & $<0.030$ \\
\hline 40 & South shore & 383936 & 1184545 & $6 / 02 / 00$ & Tui chub & A & 29 & 312 & 2.98 & 0.835 \\
\hline \multirow[t]{4}{*}{41} & West shore & 383900 & 1184500 & $5 / 17 / 01$ & Tui chub & $\mathrm{J}$ & 10.7 & 17.3 & 0.380 & 0.088 \\
\hline & & & & $5 / 17 / 01$ & Tui chub & $\mathrm{J}$ & 13.9 & 39.4 & 0.385 & 0.094 \\
\hline & & & & $5 / 17 / 01$ & Tui chub & $\mathrm{J}$ & 18.2 & 93.5 & 0.525 & 0.130 \\
\hline & & & & $5 / 17 / 01$ & Tui chub & $\mathrm{J}$ & 19.7 & 112 & 0.463 & 0.116 \\
\hline
\end{tabular}


Table 5. Concentrations of total mercury in common loons from Walker Lake, Nevada, 1998-2001

Abbreviation and symbols: g, gram; $\mu \mathrm{g} / \mathrm{g}$, microgram per gram; $\leq$, less than or equal to; $>$, greater than.]

\begin{tabular}{|c|c|c|c|c|c|c|}
\hline \multirow[b]{2}{*}{ Lake/tissue } & \multirow{2}{*}{$\begin{array}{l}\text { Season/weight } \\
\text { distinction }\end{array}$} & \multirow{2}{*}{$\begin{array}{l}\text { Number of } \\
\text { samples }\end{array}$} & \multicolumn{3}{|c|}{ Total mercury, in $\mu \mathbf{g} / \mathbf{g}^{a}$} & \multirow{2}{*}{$\begin{array}{l}\text { Percent } \\
\text { above known } \\
\text { risk level }^{\text {b }}\end{array}$} \\
\hline & & & $\begin{array}{l}\text { Arithmetic } \\
\text { mean }\end{array}$ & $\begin{array}{l}\text { Standard } \\
\text { deviation }\end{array}$ & Range & \\
\hline \multicolumn{7}{|c|}{ Walker Lake } \\
\hline Blood & none & 94 & 2.96 & 1.72 & 0.2 to 9.5 & 52 \\
\hline Blood & Spring $^{\mathrm{c}}$ & 57 & 3.21 & 1.92 & 0.2 to 9.5 & 56 \\
\hline Blood & Fall $^{\mathrm{d}}$ & 37 & 2.59 & 1.26 & 0.4 to 5.4 & 46 \\
\hline Blood & $\leq 4,000 \mathrm{~g}$ & 46 & 2.13 & 1.31 & 0.2 to 5.4 & 30 \\
\hline Blood & $>4,000 \mathrm{~g}$ & 48 & 3.76 & 1.71 & 0.6 to 9.5 & 75 \\
\hline Feather & none & 93 & 19.9 & 20.5 & 1.4 to 131.0 & 27 \\
\hline Feather & Spring $^{c}$ & 56 & 17.0 & 15.4 & 1.4 to 70.8 & 20 \\
\hline Feather & Fall $^{\mathrm{d}}$ & 37 & 24.1 & 25.6 & 5.4 to 131.0 & 35 \\
\hline Feather & $\leq 4,000 \mathrm{~g}$ & 45 & 22.2 & 26.8 & 3.5 to 131.0 & 27 \\
\hline Feather & $>4,000 \mathrm{~g}$ & 48 & 17.8 & 11.7 & 1.4 to 54.1 & 27 \\
\hline \multicolumn{7}{|c|}{ Topaz Lake } \\
\hline Blood & none & 2 & 0.66 & 0.18 & 0.5 to 0.8 & 0 \\
\hline Feather & none & 2 & 2.12 & 0.54 & 1.7 to 2.5 & 0 \\
\hline
\end{tabular}

${ }^{\mathrm{a}}$ Mercury concentrations in blood are expressed as wet weight and in feathers as fresh weight

${ }^{\mathrm{b}} \mathrm{Known}$ risk level is more than $3.0 \mu \mathrm{g} / \mathrm{g}$ (wet weight) for blood mercury and more than $20.0 \mu \mathrm{g} / \mathrm{g}$ (fresh weight) for feather mercury.

${ }^{\mathrm{c}}$ Mid to Late April

${ }^{\mathrm{d}}$ Late October

loon size (but dependent on age). Feather mercury levels can indicate long-term body burden accumulation, particularly for birds that ingest more mercury than what their body can depurate and demethylate (Burger 1993). Evers and others (1998) documented significant increases in feather mercury levels in recaptured individual loons over time. Therefore, within a population cohort, older loons are more likely to have higher body burdens of mercury than younger loons.

Four lines of evidence indicate common loons are accumulating mercury from Walker Lake. First, loons staging on Walker Lake likely overwinter in either the Gulf of California or the Pacific Coast along California and Baja California. Sampling efforts in these areas post-1969 indicate no significant mercury sources to piscivorous birds (Blus and others, 1974; Anderson and others, 1977; Ohlendorf and others, 1985). Additional support stems from widespread sampling that began in 1998 of wintering common loons on the coasts of the Atlantic, Gulf of Mexico, and Pacific. More than 100 individual loons have been sampled and all had blood mercury levels of $<1.0 \mu \mathrm{g} / \mathrm{g}$ (BioDiversity Research Institute, unpublished data, 2004). Common loons on Walker Lake have levels that range from 0.15 to $9.5 \mu \mathrm{g} / \mathrm{g}$ (wet weight) and 87 percent have levels greater than the upper limits found in marine systems $(1.0 \mu \mathrm{g} / \mathrm{g}$, wet weight).

Second, the proximity of wintering areas on the West Coast and the staging area at Walker Lake strongly suggests that in spring loons migrate directly from marine systems (Gulf of
California or the Pacific Ocean) to Walker Lake without stopping elsewhere and being exposed to mercury. Loon blood sampling efforts during the spring were conducted during the peak abundance of staging loons in mid-April. Field observations indicated that most loons remain at Walker Lake for less than two weeks. Spring migrants arrive in early April and by late April most have migrated northward. Loons exhibit the age-related differential migratory behavior common in longdistance migrants, where adults migrate before younger age classes (Berthold 2001). Our sampling efforts reflect only adults (more than 2 years of age) during spring and fall migration. (Larry Neel, Nevada Department of Wildlife, oral commun., 2002; Jim Paruk, Northland College, oral commun., 2002). Fall migration begins in early October and ends in mid-November.

Third, concentrations of mercury in loons staging at Walker Lake are in the range that would be expected given the mercury concentrations in loon prey from Walker Lake. Mercury concentrations from tui chub are elevated in fish that are $10-20 \mathrm{~cm}$, and greatly elevated in fish greater than $25 \mathrm{~cm}$ fish (with most samples 0.6 to $0.9 \mu \mathrm{g} / \mathrm{g}$ wet weight, whole body mercury). In New England, breeding common loons feeding on fish containing more than $0.15 \mu \mathrm{g} / \mathrm{g}$ mercury (wet weight, whole body) had blood mercury levels exceeding the lowest observed adverse-effect level (Evers and others, 2003a). Barr (1996) found that the preferred prey size for common loons was 


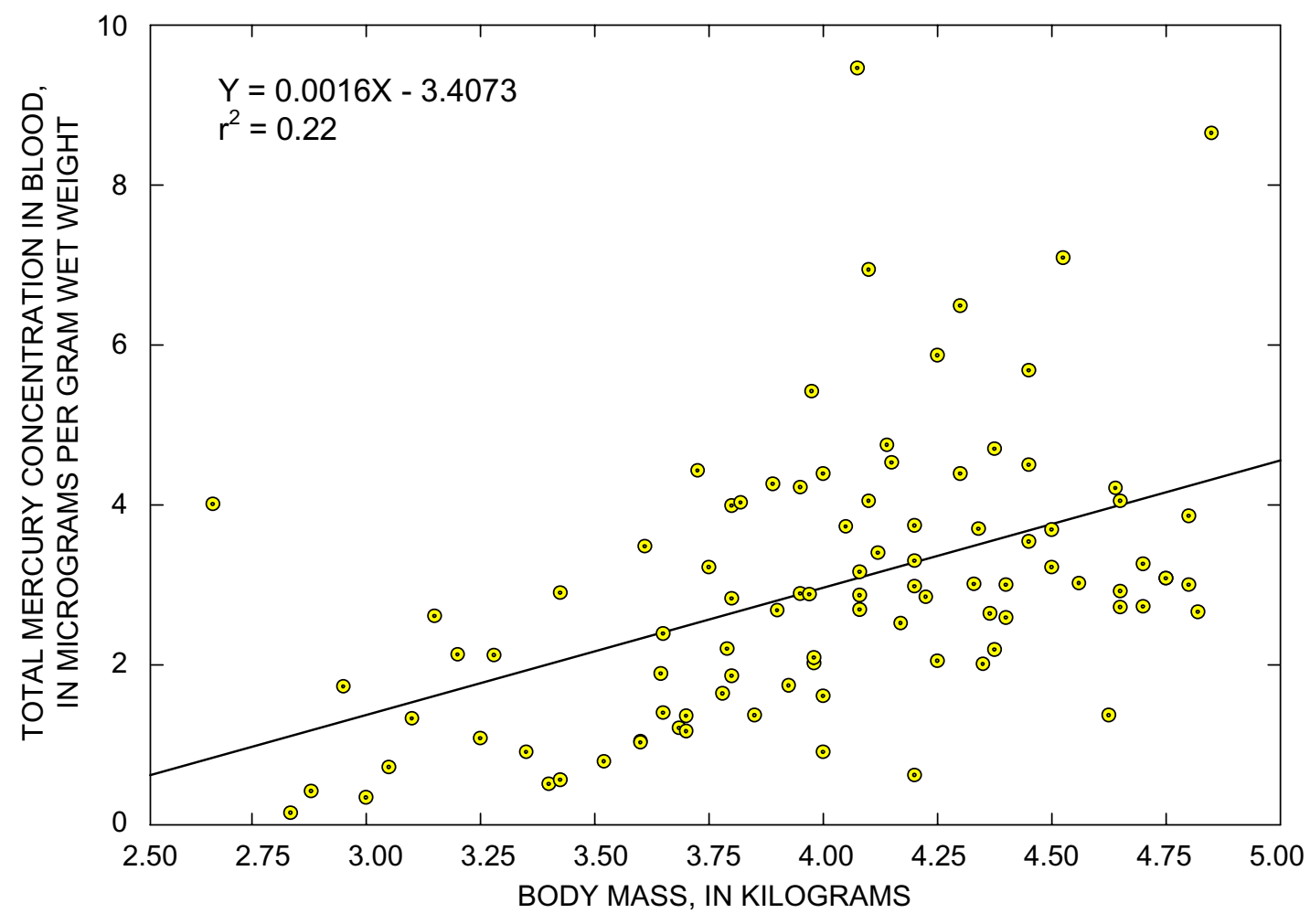

Figure 5. Graph showing relation between body weight and total-mercury concentration in blood from common loons at Walker Lake, Nevada.

greater for fish with fusiform shapes (such as tui chub) than for fish with spiny rays. Therefore, common loons most likely are eating larger fish. Based on comparable data sets from breeding common loons in Maine and migrant common loons in Nevada, the regression model predicts mercury concentrations in tui chubs from Walker Lake is linked to mercury in the blood of staging common loons (fig. 6).

Fourth, dietary mercury is quickly reflected in bird blood (Kambamandi-Dimou and others, 1991), thus, the amount of time spent by loons at Walker Lake is ample for the observed bioaccumulation of mercury in loon blood from prey fish. In oral-dosing studies with loon chicks, dietary mercury was seen in the blood within 12 hours (Fournier and others, 2002).

The negative physiological effect of elevated mercury concentrations in the prey of common loons using Walker Lake is potentially significant, particularly for spring migrants. Spring migrants identified as having high risk are likely to have reproductive effects because (1) the half-life of methylmercury in the blood of loon chicks is 116 days (Fournier and others, 2002), (2) egg mercury concentrations are strongly related to female blood levels ( ${ }^{2}=0.82$; Evers and others, 2003b), and (3) incubating behavior is significantly altered in high risk individuals and is related to lower overall reproductive success (Evers and others, 2003a).

Studies were done that track common loons using satellite telemetry show that Walker Lake migrants breed in west-central Saskatchewan and have a spring arrival between late April and early May (Yates, 1999; Yates, M.A., Center for Conservation Research and Technology, written commun., 2002).
Egg-laying by loons that stage at Walker Lake begins approximately 3-4 weeks after leaving Walker Lake. In that time, blood methylmercury levels may be reduced by approximately 18-24 percent by depuration and demethylation (assuming the blood mercury half-life in loon chicks is similar to breeding adults). Common loon populations are not currently being monitored at the breeding sites and, therefore, population-level impacts related to mercury are unknown.

Adverse effects from mercury concentrations to common loons staging at Walker Lake in the fall are less likely because average blood mercury concentrations tended to be lower in the fall $(2.6 \mu \mathrm{g} / \mathrm{g})$ than in the spring $(3.2 \mu \mathrm{g} / \mathrm{g})$. In addition, individuals likely overwinter in marine environments, which have lower methylmercury availability compared to fresh water systems (Welch, 1994; BioDiversity Research Institute unpublished data, 2004), thus providing approximately five months for contaminated individual loons to demethylate and depurate mercury.

\section{Implications of Mercury to the Walker River Ecosystem}

Mercury concentrations measured in sediment from streams in the Walker River Basin are high enough that adverse effects on aquatic invertebrate communities may be found. The lower tenth percentile toxicity value for mercury in sediment (Effects Range-Low) is $150 \mathrm{ng} / \mathrm{g}$ (dry weight) and the median toxicity value (Effects Range-Median) is 1,300 ng/g (Long and Morgan, 1991). Mercury concentrations in 


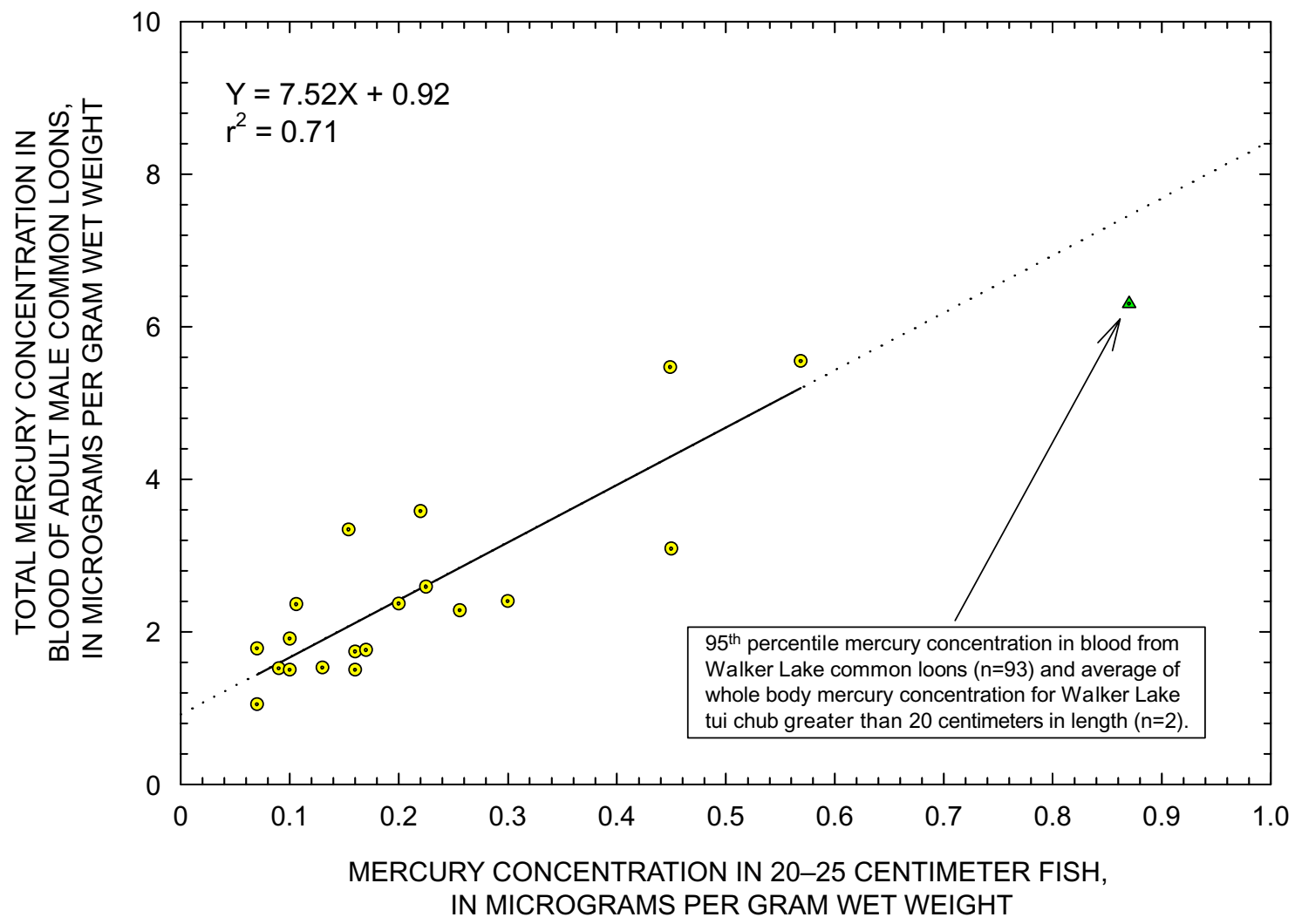

Figure 6. Graph showing relation between total-mercury concentration in 20-25 centimeter yellow perch and blood from common loons collected in western Maine (BioDiversity Research Institute, written commun., 2002). Data point for common loons and tui chub from Walker Lake shows exposure in Walker Lake.

streambed sediment exceeded $150 \mathrm{ng} / \mathrm{g}$ at ten sites and exceeded $1,300 \mathrm{ng} / \mathrm{g}$ at one site. In surficial sediments (less than $15 \mathrm{~cm}$ ) in the lakes and reservoirs, mercury concentrations exceeded $200 \mathrm{ng} / \mathrm{g}$ at most sites in Weber Reservoir and Walker Lake. The sediment effects threshold for mercury in freshwater invertebrates is $200 \mathrm{ng} / \mathrm{g}$ (Persaud and others, 1993), which was exceeded at nine stream sites. One stream sample exceeded $1,060 \mathrm{ng} / \mathrm{g}$, a consensus-based probable effects concentration for mercury in freshwater ecosystems (MacDonald and others, 2000), and another stream sample containing 1,040 ng/g approached that level.

Risk of reproductive failure has been documented in common loons foraging on prey with more than $0.30 \mu \mathrm{g} / \mathrm{g}$ total mercury on a wet-weight basis (Barr, 1986) with some individual loons impacted from foraging on fish with total-mercury concentrations between 0.15 and $0.30 \mu \mathrm{g} / \mathrm{g}$ (Evers and others, 2003a). Because of their size and abundance, tui chub are the most likely prey of common loons using Walker Lake during the spring. Given the concentrations of mercury found in Walker Lake tui chub samples, reproductive effects are possible in common loons that consume tui chub from Walker Lake.

Additional information is needed for mercury concentrations in whole bodies of older and larger fish from Walker Lake to determine if they might be adversely affected. Department of the Army (undated) found up to $1.0 \mu \mathrm{g} / \mathrm{g}$ mercury (wet weight) in tui chub from Walker Lake in 1994 and the Nevada Department of Wildlife found up to $0.86 \mu \mathrm{g} / \mathrm{g}$ mercury (wet weight) in fillets of Lahontan cutthroat trout in 1999 (Michael Sevon, Nevada Division of Wildlife, written commun., 1999). Typically, mercury concentrations in fish increase with the size or age of fish (Wiener and others, 2003). Niimi and Kissoon (1994) reported that 1 to $5 \mu \mathrm{g} / \mathrm{g}$ mercury (wet weight) in rainbow trout (Oncorhynchus mykiss) was the chronic effects estimate. However, Wiener and Spry (1996) associated higher whole body concentrations with sublethal or lethal effects in brook trout (Salvelinus fontinalis; $5 \mu \mathrm{g} / \mathrm{g}$ wet weight) and rainbow trout $(10 \mu \mathrm{g} / \mathrm{g})$, with the no-observed-effect concentration in salmonids being $3 \mu \mathrm{g} / \mathrm{g}$ in whole body. Variations in sensitivity within and among species may lead to uncertainty in estimates of critical tissue concentrations (Wiener and others, 2003). Mercury concentrations much lower than those associated with overt toxicity may adversely affect fish behavior and mercury also may adversely affect reproductive success (Wiener and others, 2003).

More data is needed for mercury residues in fish from Weber Reservoir. Fish in Weber Reservoir may be at risk because the reservoir is the first reservoir downstream from mining activities in the Bodie and Aurora areas and mercury concentrations in sediment were elevated.

The threat of mercury to fish-eating species other than common loons that feed at Walker Lake is difficult to predict as some do not spend extended periods there, but may also be exposed to mercury in the adjacent Carson River basin (Henny and others, 2002). One example is the American white pelican 
(Pelecanus erythrorhynchos) that nests at Anaho Island in Pyramid Lake, and feeds in several river basins, including the Carson and Walker River basins, and specifically in Walker Lake. Hatching success of this colony appeared normal in 1996; however, exposure of some birds may have been excessive (Wiemeyer and others, 2001). Information on mercury exposure to other avian species that use Walker Lake, such as western and Clark's grebes, is needed.

\section{Summary}

In 1998, analyses of blood samples from six common loons collected from Walker Lake by BioDiversity Research Institute revealed that three of the birds had greatly elevated blood mercury levels. Between 1999 and 2001, the U.S. Geological Survey collected samples of water and sediment and the U.S. Fish and Wildlife Service collected biological samples to determine the sources and distribution of mercury in the Walker River basin and to evaluate potential effects on the ecosystem. BioDiversity Research Institute continued sampling blood in common loons from 1999 to 2001.

In the Walker River basin, total-mercury concentrations in stream-water samples collected during 2000 and 2001 ranged from 0.62 to $57.11 \mathrm{ng} / \mathrm{L}$. All but one sample were less than $15 \mathrm{ng} / \mathrm{L}$, the upper limit for three uncontaminated mountain streams in the East Fork of the Carson River drainage basin. This, however, does not indicate that the Walker River basin is uncontaminated. Relatively few water samples were collected, and in addition samples were collected during low flow in late summer whereas samples collected during spring runoff likely would contain greater mercury concentrations.

The total-mercury concentration in lake and reservoir water samples ranged from $1.02 \mathrm{ng} / \mathrm{L}$ to $26.8 \mathrm{ng} / \mathrm{L}$. The totalmercury concentration in a sample from Walker Lake was very low, only $1.87 \mathrm{ng} / \mathrm{L}$. Mercury from mining activities in buried sediments could be the source of mercury now present in lake water. Alternatively, mercury from mining activities could have been buried in lake sediments and the mercury now present in the lake and stream is from naturally occurring sources.

Mercury concentrations in streambed sediment samples collected during 2000 and 2001 in the Walker River Basin ranged from $1 \mathrm{ng} / \mathrm{g}$ to $13,600 \mathrm{ng} / \mathrm{g}$ for total mercury and 0.07 to $32.1 \mathrm{ng} / \mathrm{g}$ for methylmercury. Total-mercury concentrations exceeding $200 \mathrm{ng} / \mathrm{g}$ are found in several tributaries of the East Walker River where mining activities occurred during the $19^{\text {th }}$ century. The greatest total-mercury concentration, $13,600 \mathrm{ng} / \mathrm{g}$, was found in Bodie Creek, downstream from Bodie, California. Total-mercury concentrations in aquatic invertebrates ranged from $0.025 \mu \mathrm{g} / \mathrm{g}$ to $0.863 \mu \mathrm{g} / \mathrm{g}$ dry weight. The highest mercury concentrations found in invertebrates collected from any of the tributaries were from the Rough Creek drainage, and the highest concentration was in cranefly larvae in Bodie Creek.

Both the distribution of mercury in sediment and biological samples in the Walker River Basin, and the depth profile for mercury in Walker Lake sediment indicate $19^{\text {th }}$ century mining operations were a major source of mercury. Depth profiles of mercury concentrations for sediment cores from three locations in Walker Lake show peak mercury concentrations exceeding $1,000 \mathrm{ng} / \mathrm{g}$ at depths of more than $15 \mathrm{~cm}$ below lake bottom. Concentrations of mercury in sediments near the surface are substantially smaller than the peak concentrations, but also are substantially higher than mercury concentrations at depths greater than $56 \mathrm{~cm}$, which likely represents background mercury concentrations for the Walker River Basin.

The main source of mercury appears to be the drainages associated with amalgamation operations in the Aurora and Bodie mining districts near the headwaters of Rough Creek. Nonetheless, mercury is naturally enriched in gold deposits and geothermal waters and the possibility exists that mercury from amalgamation operations has been buried and the mercury currently moving through the system is from natural sources. The available data are insufficient to evaluate this possibility and additional studies are needed to estimate how much of the mercury currently moving through the system can be attributed to natural sources.

Tui chub from Walker Lake are the principal food item for the common loon, which rest and feed at Walker Lake during their migration. The relation between body size and mercury content is typically explained as larger individuals being older and having been exposed longer; however, blood mercury content varies, for the migratory loons and is likely related to larger loons consuming larger prey than smaller loons. Mercury concentrations in tui chub up to $20 \mathrm{~cm}$ in length, the size most commonly consumed by loons, were consistently less than $0.25 \mu \mathrm{g} /$ $\mathrm{g}$ (wet weight), however, mercury concentrations in tui chub greater than $25 \mathrm{~cm}$ in length were significantly higher (up to $0.91 \mu \mathrm{g} / \mathrm{g}$ ). It is the mercury concentrations in the larger tui chub that are of greatest concern and are likely responsible for common loon blood mercury levels that are elevated.

Common loons apparently accumulate large amounts of mercury while staging at Walker Lake. One loon captured at Walker Lake in late spring 2001 had a mercury blood level of $9.46 \mu \mathrm{g} / \mathrm{g}$, which is the highest level recorded for more than 1,600 adult common loons analyzed across North America. The mean mercury concentration in blood from 94 common loons from Walker Lake was $2.96 \mu \mathrm{g} / \mathrm{g}$, whereas the North American mean level was $1.72 \mu \mathrm{g} / \mathrm{g}$. According to risk assessments conducted for northeastern North America, blood mercury concentrations exceeding $3.0 \mu \mathrm{g} / \mathrm{g}$ cause behavioral, reproductive, and physiological effects in common loons. Sampling efforts based on blood and feather mercury concentrations indicate 52 and 27 percent, respectively, of the breeding loons at Walker Lake are at risk for adverse effects from mercury. The blood concentrations indicate the greatest risk is to large loons using the lake as a spring staging area. The data collected indicate mercury most likely is adversely affecting the well being and reproduction of fish and wildlife using Walker Lake. Mercury concentrations in streambed sediment in the Walker River system are similar to those found in the Carson River system. Additional data are needed to assess risk to other species of birds which also use Walker Lake, such as pelicans and grebes, to assess the publichealth risk from consuming fish from Walker Lake. 


\section{References Cited}

Anderson, D.W., Jurek, R.M., and Keith, J.O., 1977, The status of brown pelicans at Anacapa Island in 1975: California Fish Game, vol. 63, p. 4-10.

Appleby, P.G., and Oldfield, F., 1978, The calculation of lead210 dates assuming a constant rate of supply of unsupported

${ }^{210} \mathrm{~Pb}$ to the sediment: Catena, vol. 5, p. $1-8$.

Bailey, E.H., and Phoenix, D.A., 1944, Quicksilver deposits in Nevada: University of Nevada Bulletin, Geology and Mining Series 41, 206 p.

Barr, J.F., 1986, Population dynamics of the common loon (Gavia immer) associated with mercury contaminated waters in northwestern Ontario: Canadian Wildlife Service, Ottawa, Ontario, Occasional Paper 56, 25 p.

Barr, J.F., 1996, Aspects of Common Loon (Gavia immer) feeding biology on its breeding ground: Hydrobiologia, vol. 321, p. 119-144.

Benoit, J.M., Gilmour, C.C., Mason, R.P., and Heyes, A., 1999, Sulfide controls on mercury speciation and bioavailability to methylating bacteria in sediment porewaters: Environmental Science and Technology, vol. 33, p. 951-957.

Benson, L.V., and Spencer, R.J., 1983, A hydrochemical reconnaissance study of the Walker River Basin, California and Nevada: U.S. Geological Survey Open-File Report 83-740, p. 53

Berthold, Peter, 2001, Bird migration: A general survey: Oxford Univ. Press, New York, New York, 253 p.

Blum, Mitchell, Gustin, M.S., Swanson, Sherman, and Donaldson, S.D., 2001, Total and methylmercury in water and sediments of Steamboat Creek, Nevada-Implications for stream restoration: Journal of the American Water Resources Association, vol. 37, p. 795-804.

Blus, L.J., Belisle, A.A., and Prouty, R.M., 1974, Relations of brown pelican to certain environmental pollutants: Pesticide Monitoring Journal, vol. 7, p. 181-194.

Burger, Joanna, 1993, Metals in avian feathers-Bioindicators of environmental pollution: Reviews in Environmental Toxicology, vol. 5:203-311.

Burgess, N.M., Evers, D.C., Kaplan, J.D., Duggan, M., and Kerekes, J.J., 1998, Mercury and reproductive success of Common Loons breeding in the Maritimes. p. 104-109 in Mercury in Atlantic Canada: A progress report: Environment Canada-Atlantic Region, Sackville, New Brunswick.

Department of the Army, undated, Receiving water biological study No. 32-EE-2435-95. Environmental sampling of Hawthorne Firing Range on Walker Lake, Hawthorne Army Depot, Hawthorne, Nevada, 1-5 May, 1995. U.S. Army Center for Health Promotion and Preventive Medicine, $55 \mathrm{p}$.

Eakins, J.D., and Morrison, R.T., 1978, A new procedure for the determination of lead-210 in lake and marine sediments: International Journal of Applied Radiation and Isotopes, vol. 29 , p. 531-536.
Engstrom, D.R., and Swain, E.B., 1997, Recent declines in atmospheric mercury deposition in the upper Midwest: Environmental Science and Technology, vol. 31, no. 4, p. 960-967.

Evers, D.C., 2001, Common Loon population studies-Continental mercury patterns and breeding territory philopatry: Ph.D. dissertation, Univ. Minn., St. Paul, Minn., 102 p.

Evers, D.C., 2003, Status assessment and conservation plan for the Common Loon (Gavia immer) in North America. U.S. Fish Wildlife Service, Hadley, Massachusetts., 94 p.

Evers, D.C., Kaplan, J.D., Meyer, M.W., Reaman, P.S., Braselton, W.E., Major, A., Burgess, Neil, and Schuehammer, A.M., 1998, Geographic trend in mercury measured in common loon feathers and blood: Environmental Toxicology and Chemistry, vol. 17, no.2, p. 173-183.

Evers, D.C., Lane, O.P., Savoy, L., and DeSorbo, Christopher, 2003a, Assessing the impacts of methylmercury on piscivorous wildlife using a wildlife criterion value based on the Common Loon, 1998-2002: Report BRI 2003-07 submitted to the Maine Department of Environmental Protection. BioDiversity Research Institute, Falmouth. Maine, 63 p.

Evers, D.C., Taylor, K.M., Major, A., Taylor, R.J., Poppenga, R.H., and Scheuhammer, A.M., 2003b, Common Loon eggs as indicators of methylmercury availability in North America: Ecotoxicology, vol. 12, p. 69-81.

Fischer, Peter, and Gustin, M.S., 2002, Influence of natural sources of mercury in water, sediment, and aquatic biota in seven tributary streams of the East Fork of the Upper Carson River, California: Water, Air, and Soil Pollution, vol. 133, p. 283-295.

Fitzgerald, W.F., Engstrom, D.R., Mason, R.P., and Nater, E.A., 1998, The case for atmospheric mercury contamination in remote areas: Environmental Science and Technology, vol. 32, no. 1, p. 1-7.

Fournier, F., Karasov, W.H., Kenow, K.P., Meyer, M.W., and Hines, R.K., 2002, The oral bioavailability and toxicokinetics of methylmercury in common loon (Gavia immer) chicks: Comparative Biochemistry and Physiology Part A 133, p. 703-714.

Garside, L.J., and Schilling, H.H., 1979, Thermal waters of Nevada: Nevada Bureau of Mines and Geology Bulletin 91, $163 \mathrm{p}$.

Gustin, M.S., Taylor, G.E., and Leonard, T.L., 1994, High levels of mercury contamination in multiple media of the Carson River drainage basin of Nevada-Implications for risk assessment: Environmental Health Perspective, vol. 102, no. 2, p. 772-778.

Hahne, H.C.H., and Kroontje, C., 1973, Significance of $\mathrm{pH}$ and chloride concentration on behavior of heavy metal pollutants-Mercury(II), Cadmium(II), Zinc(II, and Lead(II): Journal of Environmental Quality, vol. 2, no. 4, p. 444-450.

Henny, C.J., Hill, E.F., Hoffman, D.J., Spalding, M.G., and Grove R.A., 2002, Nineteenth century mercury: Hazard to wading birds and cormorants of the Carson River, Nevada: Ecotoxicology, vol. 11, p. 213-231. 
Hill, J.M., 1915, Some mining districts in northeastern California and northwestern Nevada: U.S. Geological Survey Bulletin 594, 200 p.

Hoffman, R.J., and Taylor, R.L., 1998, Mercury and suspended sediment, Carson River Basin, Nevada - Loads to and from Lahontan Reservoir in flood year 1997 and deposition in reservoir prior to 1983: U.S. Geological Survey Fact Sheet FS-001-98, 6 p.

Hoffman, R.J., and Thomas, K.A., 2000, Methylmercury in water and bottom sediment along the Carson River system, Nevada and California, September 1988: U.S. Geological Survey Water-Resources Investigations Report 00-4013, $17 \mathrm{p}$.

Horton, G.A., 1996, Walker River chronology: A chronological history of the Walker River and related water issues: Nevada Department of Conservation and Natural Resources, Division of Water Planning, Carson City, Nevada, mixed pagination.

Horton, G.A., 1997, Carson River chronology-A chronological history of the Carson River and related water issues: Nevada Department of Conservation and Natural Resources, Division of Water Planning, Carson City, Nevada, mixed pagination.

Kambamandi-Dimou, Anastasia, Kamarianos, Athanasios, and Kilikidis, Stylianos, 1991, Transfer of methylmercury to hen's eggs after oral administration: Bulletin of Environmental Contamination and Toxicology, vol. 46, p. 128-133.

Kamman, N.C., and Engstrom, D.R., 2002, Historical and present fluxes of mercury to Vermont and New Hampshire lakes inferred from $210 \mathrm{~Pb}$ dated sediment cores: Atmospheric Environment, vol. 36, p. 1599-1609.

Koch, D.L., Cooper, J.J., Lider, E.L., Jacobson, R.L., and Spencer, R.J., 1979, Investigations of Walker Lake, Nevada-Dynamic ecological relationships: Bioresources Center, Desert Research Institute, University of Nevada System, Reno, Nevada, 203 p.

Krabbenhoft, D.P., Wiener, J.G., Brumbaugh, W.G., Olson, M.L., DeWild. J.F., and Sabin, T.J., 1999, A national pilot study of mercury contamination of aquatic ecosystems along multiple gradients: in U.S. Geological Survey Toxic Substances Hydrology Program-Proceedings of the Technical Meeting, Charleston, South Carolina, March 8-12, 1999-Volume 2 of 3-Contamination of Hydrologic Systems and Related Ecosystems: U.S. Geological Survey Water-Resources Investigations Report 99-4018B, p. 147-160.

Lawrence, S.J., 1998, Trace-element enrichment in streambed sediment and crayfish, Carson and Truckee Rivers, Nevada and California, September 1992: U.S. Geological Survey Water-Resources Investigations Report 97-4258, 16 p.

Long, E.R., and Morgan, L.G., 1991, The potential for biological effects of sediment sorbed contaminants tested in the National Status and Trends Program: U.S. National Oceanographic and Atmospheric Administration, NOAA Technical Memorandum NOS OMA 52, 175 p.
MacDonald, D.D., Ingersoll, D.G., and Berger, T.A., 2000, Development and evaluation of consensus-based sediment quality guidelines for freshwater ecosystems: Archives of Environmental Contamination and Toxicology, vol. 39, p. 20-31.

Meyer, M.W., Evers, D.C., Hartigan, J. J., and Rasmussen, P.S., 1998, Patterns of common loon (Gavia immer) mercury exposure, reproduction, and survival in Wisconsin, USA: Environmental Toxicology and Chemistry, vol. 17, no. 2, p. 184-190.

Miller, J.R., Lechler, P.J., Desilets, Mario, 1998, The role of geomorphic processes in the transport and fate of mercury in the Carson River basin, west-central Nevada: Environmental Geology, vol. 33, no. 4, p. 249-262.

Monk, H.E., 1961, Recommended methods of analysis of pesticide residues in food stuffs: Report by the Joint Mercury Residue Panel. Analyst, vol. 86, p. 608-614.

Moore, J.G., 1969, Geology and mineral deposits of Lyon, Douglas, and Ormsby Counties, Nevada: Nevada Bureau of Mines and Geology Bulletin 75, Reno, Nevada, 45 p.

Nevada Bureau of Water Quality Planning, 1998, Water Quality Regulations - Water pollution control: Nevada Administrative Code, chap. 445A, p. 40-138.

Nevada Environmental Commission, 1991, Water Pollution Control Regulations; Nevada Revised Statutes, Chap. 445, $162 \mathrm{p}$.

Niimi, A.J., and Kisson, G.P., 1994, Evaluation of the critical body burden concept based on inorganic and organic mercury toxicity to rainbow trout (Onchorynchus mykiss): Archives of Environmental Contamination and Toxicology, vol. 27, p. 169-178.

Ohlendorf, H.M., Anderson, D.W., Boellstorff, D.E., and Mulhern, B.M., 1985, Tissue distribution of trace elements and DDE in brown pelicans: Bulletin of Environmental Contamination and Toxicology, vol. 35, p. 183-192.

Olson, M.L., and DeWild, J.F., 1999, Low-level techniques for the collection and species-specific analysis of low levels of mercury in water, sediment, and biota, in Morganwalp, D.W., and Buxton, H.T., eds., U.S. Geological Survey Toxic Substances Hydrology Program, Proceedings of the technical meeting, Charleston, S.C., March 8-12, 1999. Volume 2: Contamination of hydrologic Systems and related ecosystems: U.S. Geological Survey Water-Resources Investigations Report 99-4018B, p. 191-200.

Paher, S.W., 1980, Nevada ghost towns and mining camps: Howell-North Books, San Diego, Calif., 492 p.

Persaud, Deo, Jaagumagi, Rein, and Hayton, Alan, 1993, Guidelines for the protection and management of aquatic sediment quality in Ontario: Ontario Ministry of the Environment and Energy, Ontario, 27 p.

Ross, D.C., 1961, Geology and mineral deposits of Mineral County, Nevada: Nevada Bureau of Mines and Geology Bulletin 58, Reno, Nevada, 98 p. 
Scheuhammer, A.M., Atchison, C.M., Wong, A.H.K., and Evers, D.C., 1998, Mercury exposure in breeding Common Loons (Gavia immer) in central Ontario, Canada: Environmental Toxicology and Chemistry, vol. 17, no. 2, p. 191-196.

Shelton, L.R., and Capel, P.D., 1994, Guidelines for collecting and processing samples of stream- bed sediment for analysis of trace elements and organic contaminants for the National Water-Quality Assessment Program: U.S. Geological Survey Open-File Report 94-458, 20 p.

Smith, G.H., 1943, The history of the Comstock Lode, 18501920: University of Nevada Bulletin, vol. 37, no. 3, 305 p.

Stafford, C.J., and Stickel, W.H., 1981, Formalin preservation of avian blood for organochlorine analysis, in Lamb, D.W., and Kenaga, E.E., eds.: Avian and mammalian wildlife toxicology, Second Conf., ASTM STP 757, p. 93-97.

Swain, E.B., Engstrom, D.R., Brigham, M.E., Henning, T.A., and Brezonik, P.L., 1992, Increasing rates of atmospheric mercury deposition in midcontinental North America: Science, vol. 257, p. 784-787.

Thodal, C.E., and Tuttle, P.L., 1996, Field screening of water quality, bottom sediment, and biota associated with irrigation drainage in and near Walker River Indian Reservation, Nevada, 1994-95: U.S. Geological Survey Water-Resources Investigations Report 96-4214, 39 p.

Thomas, J.M., 1995, Water budget and salinity of Walker Lake, Western Nevada: U.S. Geological Survey Fact Sheet FS-115-95, 4 p.

Thomas, R.A., 2003, Characterization of total and methyl mercury in Steamboat Creek, Nevada, and implications for the Truckee River: Unpublished Masters Thesis, University of Nevada Reno, 100 p.

Thompson, D.R., 1996. Mercury in Birds and Terrestrial Animals, in Beyer, W.N., Heinz, G. H., Redmon-Norwood, A.W., eds.: Environmental Contaminants in Wildlife: Interpreting Tissue Concentrations: Clemson, South Carolina, Lewis Publisher, $494 \mathrm{p}$.

U.S. Environmental Protection Agency, 2002, National Recommended Water Quality Criteria-2002: Washington, D.C., Office of Water, U.S. Environmental Protection Agency Report EPA-882-R-02-047, 32 p.

U.S. Geological Survey, 1970, Mercury in the environment: U.S. Geological Survey Professional Paper 713, 67 p.

U.S. Geological Survey, 1998, National field manual for the collection of water-quality data: U.S. Geological Survey Techniques of Water-Resources Investigations, book 9, chap. A6, 237 p.
Van Denburgh, A.S., Goerlitz, D.F., and Godsy, E.M., 1996, Depletion of nitrogen-bearing explosives wastes in a shallow ground-water plume near Hawthorne, Nevada, in Morganwalp, D.W., and Aronson, D.A., eds., U.S. Geological Survey Toxic Substances Hydrology Program-Proceedings of the technical meeting, Colorado Springs, Colorado, September 20-24, 1993: U.S. Geological Survey WaterResources Investigations Report 94-4015, vol. 2, p. 895-904.

Wayne, D.M., Warwick, J.J., Lechler, P.J., Gill, G.A., and Lyons, W.B., 1996, Mercury contamination in the Carson River, Nevada-A preliminary study of the impact of mining wastes: Water, Air, and Soil Pollution, vol. 92, p. 391-406.

Weber, H.M., and Haines, T.A., 2003, Mercury effects on predator avoidance behavior of a forage fish, golden shiner (Notemigonus crysoleucas). Environmental Toxicology and Chemistry, vol. 22, p. 1556-1561.

Welch, L.J., 1994, Contaminant burdens and reproductive rates of Bald Eagles breeding in Maine. M.S. thesis, Univ. Maine, Orono, Maine.

Wiemeyer, S.N., Miesner, John, Tuttle, P.L., Murphy, E.C., Sileo, Lou, and DeLong, Anita, 2001, Environmental contaminants in American white pelicans breeding at Pyramid Lake, Nevada, USA: U.S. Fish and Wildlife Service, Nevada Fish and Wildlife Office, Reno, Nevada, $54 \mathrm{p}$.

Wiemeyer, S.N., Moore, J.F., and Mulhern, B.M., 1984, Formalin preservation of avian blood for metal and DDE analysis: Bulletin of Environmental Contamination and Toxicology, vol. 33, p. 525-532.

Wiener, J.G., Krabbenhoft, D.P., Heinz, G.H., and Scheuhammer, A.M., 2003, Ecotoxicology of mercury, in Hoffman, D.J., Rattner, B.A., Burton, G.A., Jr, and Cairns, J. Jr., eds.: Handbook of Ecotoxicology, $2^{\text {nd }}$ edition, Boca Raton, Florida, Lewis Press, p. 409-463.

Wiener, J.G., and Spry, D.J., 1996, Toxicological significance of mercury in freshwater fish, in Beyer, W.N., Heinz, G.H., and Redmon-Norwood, A.W., eds., Environmental contamination in Wildlife-Interpreting tissue concentrations: Lewis Publishers, Boca Raton, Florida. 494 p.

Yates, M.A., 1999, Walker Lake satellite telemetry loon study. Great Basin Birds vol. 2, p. 68-69. 